\title{
Political Activity and Firm Performance within Nonmarket Research: A Review and International Comparative Assessment
}

\author{
Authors \\ Dr Tazeeb Rajwani (corresponding author) \\ Cranfield School of Management \\ Cranfield University \\ Cranfield, Bedfordshire \\ MK43 0AL, England \\ Phone: +44 (0) 1234751122 \\ Email: Tazeeb.rajwani@cranfield.ac.uk \\ Mr. Tahiru Azaaviele Liedong \\ Cranfield School of Management \\ Cranfield University \\ Cranfield, Bedfordshire \\ MK43 OAL, England \\ Phone: +44 (0) 1234751122 \\ Email: tahiruazaaviele.liedong@cranfield.ac.uk
}




\title{
Political Activity and Firm Performance within Nonmarket
}

\section{Research: A Review and International Comparative Assessment}

\begin{abstract}
There is a widely held view that the performance of firms depends not only on the ability of managers to exploit economic markets but also on their ability to succeed in political markets. To test the value of political activism, recent scholarship has probed the impact of CPA on firm performance. However, mixed findings and the fragmented nature of the field raise more questions than provide answers to the nature of this relationship. This systematic review examines scholarly articles for evidence of the impact of CPA on firm value. The findings suggest that CPA is more valuable in emerging countries. Relational strategies dominate in emerging countries where social capital underlies political and economic exchange. The paucity of studies on informational strategies and policy outcomes in the emerging country context indicates that firms' focus on institutional entrepreneurship and global governance is poor. Consequently, we consider the implications of the findings for local and multinational enterprises, and proffer suggestions for further research.
\end{abstract}

Keywords: CIMO-logic, Corporate political activity, Firm performance, Institutional entrepreneurship, Systematic review

\section{Acknowledgements}

The authors wish to thank Dr. Colin Pilbeam and Dr. Carlos Mena for their helpful comments on previous versions of this paper. 


\section{Introduction}

In the wake of increased global competition, managers are constantly seeking ways to enhance the competitive advantage of their firms. Multinational enterprises (MNEs) are expanding into emerging markets which despite being risky environments (Henisz \& Zelner, 2010) have abundant opportunities. Exploitation of market prospects in these locations requires the management of political risks (Meznar \& Nigh, 1995; Puck, Rogers, \& Mohr, 2013). Even in developed markets, there is the need for firms in search of competitive advantage to manage political uncertainty (Hillman \& Hitt, 1999). Firms' interactions with their nonmarket environments do not only improve their transparency and corporate governance practices, but also offer opportunities to shape the opinions of the public (Griffin \& Dunn, 2004) and politicians (Doh, Lawton, Rajwani, \& Paroutis, 2014; Lawton, Doh, \& Rajwani, 2014). Hence it is increasingly becoming clearer that marketplace strategy alone is difficult to deliver superior firm performance.

A combination of both market and political strategies has been posited as the ultimate integrated strategy that confers sustained competitive advantage on firms (Baron, 1995; Lawton, McGuire, \& Rajwani, 2013). Consequently, firm performance is dependent on the ability of managers to influence their regulatory environments and exploit their economic markets (Holburn \& Vanden Bergh, 2008; Marsh, 1998). As noted by Schuler (1996), a focus on acquiring market resources while neglecting the development of political capital in the nonmarket environment could have a negative toll on competitive advantage. Corporate political activity (hereafter CPA) has gained prominence in both practice and research as a strategy firms use to influence government policy, shape their regulatory space, and drive their performance (Getz, 1997; Hillman, Keim, \& Schuler, 2004). The need for firms to 
participate in the political process is borne out of the daunting reality that almost every firm is affected by government regulation and policy (Stigler, 1971).

In recent times, firms have been described as corporate citizens in nonmarket studies (Matten \& Crane, 2005; Moon, Crane, \& Matten, 2005; Wood \& Logsdon, 2008). Corporate citizenship describes the political roles that corporations play to solve common problems (Scherer, Baumann-Pauly, \& Schneider, 2013). CPA enables firms to participate in political processes and contribute to social welfare (Alzola, 2013). In the current trend of globalization, corporations play roles and assume larger responsibilities which were and continue to be regarded as the sole responsibilities of governments (Scherer \& Palazzo, 2007). From the advocacy for appropriate laws and regulations (Neron \& Norman, 2008) to the sponsorship or endorsement of "best political candidates" (Alzola, 2013), the contribution of CPA to global governance cannot be undermined.

The underlying rationale for CPA is to improve the fortunes of the firm (Schuler, Rehbein, \& Cramer, 2002). In other words, it is intended to provide firms with access to the corridors of political power (Keim \& Zeithaml, 1986), reduce uncertainty (Hillman \& Hitt, 1999), and subsequently empower them with the ability to influence their competitive space (Capron \& Chatain, 2008; McWilliams, van Fleet, \& Cory, 2002). However, a scan of extant literature across a broad international spectrum reveals that evidence of the relationship between CPA and firm performance is still mixed. While some studies report a positive relationship between political activism and performance, other studies report the absence of a significant relationship or even a negative relationship. Hence, our knowledge of the impact of CPA on firm performance is not complete or conclusive.

Building on the special issue call for more research on 'global governance and international nonmarket strategies' in the International Business (IB hereafter) field, we find that CPA 
research in emerging and developing countries is gaining momentum, but findings show it requires more focus around outcomes. More importantly, these activities show it is not regulated or recorded well in some of these continents i.e. Africa, South America and Asia. These emerging markets, though fraught with high level political risks (Henisz \& Zelner, 2010), provide abundant investment opportunities for international firms. Weak regulatory regimes (Henisz, 2004) among a number of other institutional voids (Khanna \& Palepu, 2000) render developing countries as high risk. Consequently, the reduction of political risk exposure is one of the main motivations for political activity (Hillman \& Hitt, 1999), especially for international firms (Frynas \& Mellahi, 2003; Keillor, Wilkinson, \& Owens, 2005). Few studies (Puck et al., 2013) have assessed the impact of political activity on risk exposure of multinationals in emerging countries. This is a slice of a larger deficiency in the IB literature where there is relative paucity of studies exploring CPA outcomes for multinational enterprises in different emerging markets (MNEs) from different home countries (Holmes, Miller, Hitt, \& Salmador, 2013).

The IB field has explored various CPA factors, but much of the focus has been on the nature of MNE political behaviour (Barron, 2011; Boddewyn \& Brewer, 1994; Hillman \& Keim, 1995; Sun, Mellahi, \& Thun, 2010), the determinants of MNE political strategies (Blumentritt, 2003; Hillman, 2003; Hillman \& Wan, 2005), and MNE political strategy process (Chen, 2007; Luo \& Zhao, 2013). The performance implications of CPA for MNEs lag behind the pack. Nonetheless, a few studies have attempted to compare performance of politically active firms across multiple countries (Boubakri, Cosset, \& Saffar, 2008; Boubakri, Guedhami, Mishra, \& Saffar, 2012; Boubakri, Cosset, \& Saffar, 2012; Faccio, 2006). Though this approach does not address international business in its purest sense, it does hint at some of the important relationships between institutional environments and CPA outcomes. Such findings cast light on the value of CPA in different regions and provide a 
basis for MNEs to plan and vary their political engagement in diverse institutional environments. We believe that reviewing a large body of IB, finance, economics and political science literatures, we will reveal the nuances of the strategies, mechanisms, and outcomes of political engagement in different institutional contexts, and provide deeper insight for MNE strategic planning.

Therefore, this paper makes three distinct contributions to the CPA field, and more broadly to the IB field. Firstly, it examines, in an objective and structured manner, the empirical evidence regarding the impact of CPA on firm performance in different international contexts. Due to the fragmented and inconsistent nature of the literature, we synthesized the information following the CIMO-logic (Denyer, Tranfield, \& van Aken, 2008) as applied by Pilbeam, Alvarez, \& Wilson (2012). This method relates to the design science paradigm where the focus is on improving outcomes through the implementation of appropriate interventions. Design propositions are prescriptive (Denyer et al., 2008) and are able to provide information on what to do under what circumstances to achieve what outcomes (Pilbeam et al., 2012). By this synthesis method, we explored the contexts (C) within which CPA has been investigated, the strategies/interventions (I) implemented, the firm performance outcomes $(\mathrm{O})$ of those strategies, and the mechanisms (M) underlying the performance outcomes. Thereafter, we combined these four elements to derive a whole picture. We chose this explanatory and realist method of synthesis (Pilbeam et al., 2012) in order to understand how CPA strategies and outcomes vary in different contexts, and also to understand what mechanisms impact performance. The assumption made here is that different CPA strategies may produce different outcomes in different contexts through different mechanisms. Thus, we build on other important CPA reviews (Hillman et al., 2004; Lawton et al., 2013; Mathur \& Singh, 2011) which mainly summarized CPA research without delving deep into any of the facets of CIMO. We provide depth in understanding the impact 
of CPA on firm performance and being the first study to do so applying the CIMO-logic and using a systematic approach for paper selection (Denyer et al., 2008).

Our second contribution is in developing the future agenda on how to investigate the CPA and performance relationship in the IB field. There is a need to systematically review the current literature to create even more clarity. That way, we will not only reach conclusive evidence as to the nature of the CPA-firm performance relationship, but will also identify possible and optimal avenues to contribute to the topic by way of further research (Grant \& Booth, 2009; Tranfield, Denyer, \& Smart, 2003). The findings suggest that CPA is positively related to firm performance, an indication that there is value in political activity. Majority of the studies we find argue that CPA improves firm performance. However, counter evidence is also reported by a few studies in both developed and emerging markets. The evidence also reveals that institutional contexts influence the political strategies used by firms, the performance outcomes of those strategies, and the mechanisms through which those strategies impact performance outcomes. Even though most of the studies lack theoretical grounding, social capital, cronyism and agency relationships are the popularly cited or implied mechanisms underlying the CPA-firm performance relationship.

Finally, our paper has implications for understanding corporate governance aspects in international business, as we find that institutional variations moderate the nature and efficacy of corporate political engagement. Multinational firms with operations in emerging/developing countries and developed countries will realize that some strategies do not work and some outcomes are non-existent. The mechanisms influencing firm performance also vary with level of institutional development. We argue that CPA, a type of capability, can provide solutions to common problems and promote global governance. Moreover, it is through institutional entrepreneurship (DiMaggio, 1988), MNEs can transfer best these political practices and principles to developing countries. 
The rest of the paper is organized as follows. We present the methodology employed in this study in the next section. A descriptive account of the reviewed literature is also offered. Thematic findings are presented following the CIMO-logic (Denyer et al., 2008). These findings are subsequently synthesized and discussed. We conclude our review by hinting at the implications of the findings for firms, especially MNEs, and suggesting directions for future research.

\section{$<$ Insert Figure 1 >}

\section{Methods}

The methodology employed in conducting this systematic review followed the approach posited by Tranfield et al. (2003) and Petticrew and Roberts (2006). These studies articulate a systematic approach to review management and social sciences literature. Prior to beginning the review, we carried out a scoping study to "access the size and relevance of literature and to delimit the subject area or topic" (Tranfield et al., 2003, p.214), to identify the nature and extent of research literature (Grant \& Booth, 2009), to identify the current state of understanding of the topic (Anderson, Allen, Peckham, \& Goodwin, 2008), and to determine

the value of undertaking a systematic review (Arksey \& O'malley, 2005). The scoping process required analytical interpretation (Levac, Colquhoun, \& O'Brien, 2010) of the "theoretical, practical and methodological history debates surrounding the fields and subfields of study" (Tranfield et al., 2003, p.214-215).

Systematic review is an evidence-based approach which originated from medical sciences and healthcare, aimed to improve decision making (Tranfield et al., 2003). In management research and social sciences, this approach is a new phenomenon that is yet to gain popularity. Management reviews are typically narrative reviews which mostly provide descriptive accounts of literature, and they differ significantly from systematic reviews which 
adopt "a replicable, scientific, and transparent process..." and provide an "audit trail of reviewers' decisions, procedures and conclusions (Tranfield et al., 2003, p. 209). Hence systematic reviews attempt to reduce reviewer bias as much as possible so as to provide a critical account of evidence. They ensure rigour and transparency, and minimize the weaknesses inherent in traditional narrative reviews (Petticrew \& Roberts, 2006; Tranfield et al., 2003). Systematic review techniques reduce bias and subjectivity (Tranfield et al., 2003). They allow for a more holistic picture, and they facilitate the identification of common, general, and conclusive evidence (Tranfield et al., 2003). Unlike systematic reviews, traditional narrative reviews are "singular" accounts (Tranfield et al., 2003) and are not conclusive due to conflicting information and difficulty to determine a balance of the evidence (Petticrew \& Roberts, 2006). Systematic reviews may help advance theory by providing opportunities to challenge existing knowledge and established schools of thoughts (Petticrew \& Roberts, 2006).

\subsection{Search Strategy}

The search strategy used in this review comprised the identification of keywords, terms and phrases which we built from the literature. We initially searched two databases for articles from which we further identified articles through cross-referencing. There are two constructs in the review question. These are 1) corporate political strategies, and 2) firm performance. There are three dominant categories of CPA strategies in the literature namely: 1) financial, 2) relational, and 3) informational strategies. Drawing on several important and seminal studies, we identified the different terms, keywords and phrases used to describe CPA and firm performance. Search strings were created through a combination of the identified search terms or phrases shown. Three search strings were created for each of the three sub-domains of corporate political activity while a single string was created for firm performance. Each of 
the strings for CPA was combined with the string for firm performance, resulting in three different combinations as shown in Table 1 . Keyword searches were initially restricted to titles and abstracts.

\section{$<$ Insert Table 1 >}

\subsection{Databases}

Following the methodology of Pittaway, Robertson, Munir, Denyer, \& Neely (2004), de Menezes and Kelliher (2011), and Lawton et al. (2013), we searched the databases $\mathrm{ABI} /$ Inform and EBSCO. These databases are very comprehensive and they index a vast amount of business literature. Even though there is a degree of overlap between the two, it was still worthwhile to search both just in case any one of them missed out on a publication. An additional way we identified literature for this review was through cross referencing. The articles that were found from the databases were checked for relevant references. Table 2 summarizes the search output from the databases.

\section{<Insert Table 2>}

\subsection{Selection of Articles}

Operationalizing the search strings resulted in 2,454 articles. To ensure that only relevant papers are reviewed, the articles were scrutinized in a four-stage process based on predetermined criteria. First, we scrutinized titles to identify those that had a relation with the review question. Second we screened abstracts to identify papers that contained relevant themes. An inclusion/exclusion criterion was applied in these first two stages. Third, we scrutinized full text of the papers to confirm the presence of themes relevant to the review question. Finally, we applied the quality criteria to appraise and select the reviewed articles. 
After selecting papers based on titles, abstract and full text, these papers were appraised for quality. All relevant papers had to meet our quality appraisal criteria (see Appendix A) in order to proceed to the review stage. CPA research is nascent but is spread across journals with different rankings. In order not to fall into the trap of assuming that papers in top rated journals are necessarily good, journal ranking was not considered in the quality appraisal criteria. All criteria were scored from 1 (not at all) to 5 (completely). A minimum score of 3 in relation to each criterion was applied to select the papers that made it to the final sample. The search and evaluation process, summarized in Table 3, resulted in a final sample of 56 articles.

\section{$<$ Insert Table 3>}

Relevant data from all 56 articles were extracted to a standardized data extraction form designed to capture the methods and key findings in the literature (see Appendix C) and to develop the CIMO-framework (see Appendix D). Because of the diversity of the individual papers with regards to contexts, strategies, mechanisms and performance outcomes, broad categories were developed for each element in the CIMO framework. The selected articles come from 37 different journals and this to a certain extent indicates how fragmented the research on this particular review question is. Some of these journals belong to the IB field, but also different fields including politics, economics, finance, management, accounting, and public policy. This observation is however not surprising because CPA is a relevant phenomenon in all of the aforementioned research fields. Of all 37 journals, only six are traceable to the management field and this signals the paucity and nascence of CPA research in this domain. Finance and economics journals dominate, perhaps due to the fact that the review focuses on firm performance. All reviewed articles were published within the last 25 years, with the earliest article published in 1988. This reveals that the relationship between CPA and firm performance started to receive attention in the late 1980s. 


\section{Thematic Findings}

The findings are presented following the CIMO-logic. Accordingly, we first present findings on the 'contexts' within which the CPA-firm performance relationship has been investigated. Second, we address the 'interventions' in terms of political strategies that are used by firms. Subsequently, we present evidence on the performance 'outcomes' of CPA. Finally, we explore the 'mechanisms' through which CPA strategies impact performance outcomes.

\subsection{Contexts of CPA Research}

\subsubsection{Developed Countries}

The value of CPA in developed markets has received some attention in the literature. The majority of studies addressing this context have focused on countries such as the United States, Germany, Denmark, and Italy. Globalization, competition, and regulation are among the most cited or implied motivations of CPA research in these countries. According to Hillman et al. (1999), government has the power to define opportunity sets and shape firms' competitive environments. This consequently increases firms' involvement in policy processes in ways that advance their goals (Hillman, 2005) or stifle the competition of their rivals, especially foreign firms wanting to enter their markets (Marsh, 1998). The surge in competition has motivated firms to acquire political capital (Hersch, Netter, \& Pope, 2008), an intangible resource that has a positive long-term effect on the fortunes of firms (Hillman, 2005).

Globalization has caused trade expansion and opened up new markets. MNEs firms sign investment agreements with partners in foreign countries. Some MNEs start greenfield investments in foreign countries for which they have to deal with political risk in sovereign territories (Puck et al., 2013). MNEs also lobby their home governments for protection from 
foreign competition (Evans \& Sherlund, 2011; Lee \& Baik, 2010). These instances raise the importance of political activity as a conduit for competitive advantage (Boddewyn \& Brewer, 1994). Firms seeking to increase their competitiveness through expansion into foreign markets stand a better chance of participating in government foreign trade missions when they make "soft money" donations to politicians (Schuler, Schnietz, \& Baggett, 2002). This suggests that in as much as MNEs need to influence host government policies in order to reduce their political risk exposure, they also need to influence home government international trade policies in order to gain access to new and larger markets.

Indeed, policy influence runs through most of the popular definitions of CPA (Getz, 1997; Hillman et al., 2004). As noted by Liebman and Reynolds (2006), campaign contributions are able to influence legislation by increasing the likelihood that beneficiary politicians would sponsor laws favourable to their contributors. Regulation begets CPA, and this perhaps confirms the finding that highly regulated industries are more politically active (Hillman, 2005; Kim, 2008). Typically in a given year, a large number of issues are formulated into policy and this increases uncertainty for firms, culminating in higher transaction costs (Williamson, 1985) of doing business. The dependence of firms on external parties creates risk and uncertainty which consequently affect their performance (Hillman, 2005).

From external parties to legal systems, one of the distinctions between developed and developing countries lie in the efficacy of legal systems (Henisz \& Zelner, 2010) and level of corruption (Johnson \& Mitton, 2003; Khwaja \& Mian, 2005). In developed countries where there are well-functioning legal systems, CPA is not expected to yield substantive advantage due to the legal costs involved in favouring private interests over public interests (Goldman, Rocholl, \& So, 2009). However, research has shown that there are significant gains in political connections in countries with strong institutions (Amore \& Bennedsen, 2013). CPA is thus valuable across the world; however the channels through which value accrues to 
politically connected firms differ from country to country, owing to variations in institutional configurations and characteristics (Boubakri et al., 2012; Kim, 2008).

\subsubsection{Emerging Countries}

CPA research has begun to gain prominence in emerging and developing countries, especially in South East Asia. Privatization, economic transitions, corruption and other institutional lapses are largely the motivating factors for CPA studies in emerging countries. Let's take a look at China. She loosened her stance on communism and began to privatize some of her state owned enterprises (SOEs). The government also decentralized SOEs to "promote markets and to gradually phase out its central planning function" (Fan, Wong, \& Zhang, 2007, p. 332). However, the Chinese government still controlled some aspects of the privatization process such as the number of companies that can go public, the number of shares that can be offered in a year, and the offer price (Francis, Hasan, \& Sun, 2009). Some articles referred to this as partial privatization because the government still retained control (Fan et al., 2007; Tu, Lin, \& Liu, 2013). These controls mean that that politically connected firms could still benefit from government favours and preferential treatment (Sun, $\mathrm{Xu}, \&$ Zhou, 2011), thus generating research interest in the value of political connections (Peng \& Luo, 2000; Wu, Wu, Zhou, \& Wu, 2012). Typically, privatized firms are expected to be independent from government control. In instances where government does not relinquish control, conflicting objectives may arise (Boubakri et al., 2008) and the resultant agency problem (Jensen \& Meckling, 1976) is expected to impact firm performance. Privatized firms are perhaps attractive to CPA researchers because of the likelihood that they would still be connected to government.

According to Peng and Luo (2000), most of the CPA research has taken place in western countries, but emerging markets have a fascinating context where social capital will more 
likely compensate for the lack of market supporting institutions. Social capital from informal ties with politicians results in political favouritism (Bliss \& Gul, 2012) and cronyism (Johnson \& Mitton, 2003). The absence of strong institutions creates what some researchers call "relationship-based capitalism" (Adhikari, Derashid, \& Zhang, 2006; Bliss \& Gul, 2012; Fraser, Zhang, \& Derashid, 2006; Sun et al., 2011) where personal connections and ties influence policy and determine the market environment. Other studies (Goldman et al., 2009) argue that in well-functioning legal systems, economic gains are not expected to accrue to politically connected firms because politicians could face legal and political costs if they favour firms for private reasons than for public merit. Obviously, institutions affect the behaviour of actors in the policy process and influence the magnitude of benefits from CPA (Faccio, 2006). Government control of China's securities market presents distinctive institutional features which affect the performance of firms (Francis et al., 2009). Anticorruption reforms by the Malaysian government transformed the institutional environment and spawned enquiries into whether private gains continued to exist through political connections (Imai, 2006). Weak systems of checks and balance are institutional voids that allow politicians and firms to extract economic rents and encourage business owners to enter politics for private gains (Bunkanwanicha \& Wiwattanakantang, 2009). Some of the studies examined CPA in high corruption contexts where "social lending" (Khwaja \& Mian, 2005) or "memo-lending" (Leuz \& Oberholzer-Gee, 2006) are prevalent. Among other reasons, Claessens, Feijen, \& Laeven (2008) found Brazil an interesting context to examine CPA due to its limited level of institutional development.

It is worth mentioning that the institutional context affects the type of CPA data collected. In countries where laws regulate CPA, data is relatively easier to collect. For instance, the availability of campaign finance data in the US facilitates CPA research. Similarly, Claessens et al. (2008) are able to investigate CPA in Brazil because Brazilian laws mandate that 
campaign contributions are recorded. Holistically, studies addressing the emerging markets context touch on the many facets of the topic including how institutions shape the nature of political activity (Barron, 2011; Hillman \& Keim, 1995) and firm performance outcomes (Faccio, 2006; Kim, 2008). The search for new evidence and the eagerness for theory development and elaboration inspire the adoption of the institutional lens where the emphasis is on developing and emerging economies. According to Doh, Lawton, \& Rajwani (2012), institutional perspectives will have more relevance for CPA research due to the importance of emergent economies for international firms.

In emerging countries, elections are mostly fraught with irregularities and the transition of political power from one administration to the other embodies a risk element because of the association of policy volatilities with those events. The lack of strong institutions makes these emerging countries highly risky (Henisz \& Zelner, 2010). Yeh, Shu, \& Chiu (2013), who consider Taiwan's 2000 and 2004 elections as external shocks, investigated the outcomes of the elections on the performance of connected firms. The bad news about the health of Indonesia's Suharto filtered into the public domain, hinted at a possible political transition and threatened the political capital of connected firms (Fisman, 2001). Such events have significant implications for firms due to the prevalence of informal business-government ties in emerging countries (Adhikari et al., 2006; Francis et al., 2009).

\subsection{Interventions in CPA}

The strategic interventions used by firms to influence their policy environments and sustain competitive advantage can be grouped into three broad categories: 1) financial strategies; 2) relational strategies; and 3) informational strategies. These strategies are applied in the above-discussed contexts for the sole purpose of shaping the competitive space and improving firm performance (Hillman et al., 1999). 


\subsubsection{Financial Strategies}

The financial strategies mostly studied in CPA include political action committee (PAC) and "soft money" contributions. These tactics are meant to provide financial incentives to politicians and enable firms to gain access to decision makers (Witko, 2011). While it may seem that PAC contributions and "soft money" mean the same thing, the two are technically different (Ansolabehere, Synder, \& Ueda, 2004). Soft money contributions are non-candidate specific donations from individuals, corporations and special interest groups to political parties (Cooper, Gulen, \& Ovtchinnikov, 2010). They are for broad party building purposes and not for the promotion of specific candidates (Schuler et al., 2002). As noted by Hersch et al. (2008), while PAC contributions are made to specific candidates, "soft money" contributions are made to political parties. "Soft money" contributions are advantageous because they are not highly regulated or restricted, have no caps (Schuler et al., 2002), and can be targeted at the executive branch where key policy decisions are evolved. "Soft money" contributions were used by firms until the 2000s when it became illegal to make such donations (Hadani \& Schuler, 2013). Hence, most of the literature on financial strategies examines PAC contributions.

\subsubsection{Relational Strategies}

Relational strategy is perhaps the most complex and subjective of all political strategies in the reviewed literature. Generally, this strategy concerns firms establishing relationships with politicians mostly through co-opting them into corporate boards (Carretta, Farina, Gon, \& Parisi, 2012; Goldman et al., 2009; Hadani \& Schuler, 2013; Hillman, 2005), through business executives and top shareholders entering politics (Hillman et al., 1999; Kim, 2008; McGuire, Schneeweis, \& Naroff, 1988), or through informal relations (Adhikari et al., 2006; Fraser et al., 2006). The common construct used here is "political connections" which is 
defined differently by different researchers. Table 4 presents a summary of some key definitions of political connectedness in the literature, and highlights the subjectivity in the definition of most relational strategies.

\section{<Insert Table 4>}

Political connections are a valuable resource (Faccio, 2006; Leuz \& Oberholzer-Gee, 2006; Niessen \& Ruenzi, 2010) which reduce uncertainty (Hillman et al., 1999) and enable firms to gain private information about policy (Hadani \& Schuler, 2013). These benefits, among others, confer a competitive advantage on connected firms over their unconnected peers through the process of rent extraction from government (Hassan, Hassan, Mohamad, \& Min, 2012). Relational strategies are the most studied in the reviewed literature; 33 of 56 articles solely focus on these strategies. Perhaps, their dominance in the CPA field is attributed to their prevalence in most parts of the world.

\subsubsection{Informational Strategies}

Before laws and regulations are passed and implemented, they are first drafted into proposals for approval. At this stage, firms and other interest groups are able to make inputs by providing specific information about policy preferences to decision makers. According to McKay and Webb-Yackee (2007), competing interests battle it out to influence policy decisions and agency actions, particularly to instigate the imposition of trade barriers and trade protection from foreign competition (Marsh, 1998). Informational strategies include lobbying (Lo, 2003), petitions (Marsh, 1998) and comments (McKay \& Webb-Yackee, 2007). From the reviewed articles, these strategies are not targeted at politicians, but at government agencies where key policy issues are initiated and drafted into proposals for parliamentary and executive approval. Information strategies are the least investigated CPA 
strategies/interventions, yet these strategies present a stronger force for a move towards global governance particularly in developing countries.

\subsection{Outcomes of CPA}

There are three distinct categories of firm performance outcomes. Stock market performance entails the measurement of cumulative abnormal returns (CARs) and Buy-and-Hold abnormal returns (BHARS). The popular methodology used to measure this type of firm performance is event study. With this method, the reaction of stock markets to political events is investigated, and such events include the appointment of politicians to corporate boards (Carretta et al., 2012; Goldman et al., 2009; Hadani \& Schuler, 2013; Hillman, 2005), the sudden death of politicians (Brown, 1996) and the transition of political power (Jayachandran, 2006; Yeh et al., 2013). Other stock market performance variables include Tobin q (Wu, Wu, \& Rui, 2012) and cost of equity (Boubakri et al., 2012).

Operating performance draws on accounting data contained in annual reports. Various variables such as return on sales (ROS) (Fan et al., 2007; Hadani \& Schuler, 2013), return on investment (ROI) (Mathur \& Singh, 2011; Niessen \& Ruenzi, 2010), effective tax rates (ETR) (Adhikari et al., 2006; Richter, Samphantharak, \& Timmons, 2009), cost of debt (Bliss \& Gul, 2012), leverage (Fraser et al., 2006; Khwaja \& Mian, 2005), accruals quality (Chaney, Faccio, \& Parsley, 2011), return on assets (ROA) (Peng and Luo, 2000), and interest revenues (Carretta et al., 2012) have been used to measure operating performance. Operating performance variables are "backward looking" and do not capture intangible political capital (Hillman, 2005). Hence, they could be misleading.

As common with previous reviews (Hillman et al., 2004; Lux, Crook, \& Woehr, 2011), the impact of interest groups and firms on policy is another outcome of CPA. However policy performance, which measures the performance of firms in the policy arena, is the least 
studied of all the outcomes in the literature. Articles examining this type of outcome either study the voting patterns of politicians (Liebman \& Reynolds, 2006), the difference between proposed and adopted agency rules (McKay \& Webb-Yackee, 2007), government bailouts (Faccio, Masulis, \& McConnell, 2006) or the outcomes of petitions (Lee \& Baik, 2010; Marsh, 1998).

\section{<Insert Table 5>}

\subsubsection{Positive Performance Outcomes}

The reviewed literature suggests that there is a positive relationship between CPA and firm performance. 44 of the 56 studies provide evidence to show that CPA adds value to the firm. In Malaysia, Adhikari et al. (2006) found that politically connected firms pay lower effective taxes than non-connected firms. This finding is consistent with Richter et al. (2009) who reported that in the United States, firms which lobby more in a given year pay lower effective tax rates in the next year. Wu et al. (2012) also reported similar evidence for China where firms with politically connected managers pay lower tax rates. Politically connected firms have easier and preferential access to financing (Boubakri et al., 2012; Claessens et al., 2008; Fraser et al., 2006; Hassan et al., 2012; Leuz \& Oberholzer-Gee, 2006), are highly leveraged (Fraser et al., 2006), and have longer debt maturities (Boubakri et al., 2012). Political connections are reported to facilitate trade expansion ( $\mathrm{Lu}, 2011)$, increase the likelihood of government bailout (Faccio et al., 2006) and allow firms to pay relatively lower premiums for privatization targets ( $\mathrm{Tu}$ et al., 2013). Campaign contributions are found to increase the number of government contracts received (Witko, 2011), the likelihood to participate in foreign trade missions (Schuler et al., 2002) and the likelihood of legislators to support favourable laws (Liebman \& Reynolds, 2006). Lobbying is associated with higher academic earmarks (De Figueiredo \& Silverman, 2006), antidumping regulations and increased market 
value of firms (Marsh, 1998). Comments and petitions shift policy towards the preferred position of firms (McKay \& Webb-Yackee, 2007). The appointment of politicians to corporate boards triggers positive stock market reactions (Hillman, 2005). Similarly, campaign contributions are positively and significantly related to future abnormal returns (Cooper et al., 2010). Peng and Luo (2000) and Imai (2006) posit that political connections are positively related to ROA.

\subsubsection{Negative Performance Outcomes}

While majority of the literature found a positive CPA-firm performance relationship, there are seven studies which report evidence to the contrary. Using United States data, Aggarwal et al. (2011) found that "soft money" donations are negatively correlated with returns. They also found that donating firms acquire more and record lower abnormal returns on acquisition announcements. Similarly, Hadani and Schuler (2013) reported evidence to suggest that CPA has a negative impact on market value. Politically connected firms record poor accounting performance after privatization (Boubakri et al., 2008) and after initial public offerings (Fan et al., 2007). Connected firms also have poor accruals quality (Chaney et al., 2011) and are charged higher interest rates on loans (Bliss \& Gul, 2012). Moreover, politicians on boards of Italian banks exert a negative impact on interest revenues, loan quality, and capitalization level (Carretta et al., 2012). Ties to government add no significant value to firms perhaps due to the constraints and costs of political embeddedness (Okhmatovskiy, 2010).

\subsubsection{No Impact and Mixed Outcomes}

Two studies do not find any significant relationship between CPA and firm performance. Ansolabehere et al. (2004) found no benefits from campaign donations while Hersch et al. (2008) argue that campaign contributions do not create any financial capital. Three studies measured multiple outcomes and reported mixed outcomes. According to Faccio et al. 
(2006), while politically connected firms are able to influence bailout policies to favour them, they record poor operating performance. Similarly, Tu et al. (2013) reported that while connected firms pay lower premium for quality firms during privatization, they record lower operating and stock performance in the post privatization period.

\subsection{Mechanisms Underpinning the CPA-Firm Performance Relationship}

Five theoretical mechanisms through which CPA impacts firm performance are identified in the literature. They include resource-based view (RBV) (Barney, 1991), agency (Jensen \& Meckling, 1976), resource dependency (Pfeffer \& Salancik, 1978), institutional (Scott, 2005) and social capital theories. Some of these mechanisms are explicitly cited while others are inferred from the arguments advanced by the studies.

Social capital is the most frequently used theoretical lens for explaining the outcomes of CPA, though it is mostly implied. The establishment of political connections enables firms to develop social capital which enables them to extract rent from politicians. These rents are in the form of preferential access to finance (Claessens et al., 2008; Yeh et al., 2013) or government contracts (Witko, 2011). Social or political capital is more pronounced in relationship-based capitalisms (Adhikari et al., 2006; Bliss \& Gul, 2012; Fraser et al., 2006) where favouritism and cronyism (Johnson \& Mitton, 2003) abound. Personal level political capital adds value to firms (Sun et al., 2011) and informal connections allow government to confer private benefits on firms (Fraser et al., 2006). Campaign contributions also build social capital and facilitate access to politicians (Kim, 2008; Witko, 2011). Drawing on RBV, some studies argue that the co-optation of politicians into corporate boards adds to the resource base of firms (Hillman, 2005) and allows firms to exploit their policy environments (Niessen \& Ruenzi, 2010). 
While social capital and RBV theories are mostly associated with the positive outcomes of CPA, agency theory is applied to explicate both positive and negative outcomes. For instance, Hadani and Schuler (2013) argue that because firms are not required to disclose political spending, information asymmetry occurs between managers and shareholders and this leads to negative firm performance. They also posit that managers could pursue CPA for selfaggrandizement. Clearly, this represents a misalignment of interests between managers and shareholders. Political connections may create an agency problem where politicians use firms' resources to pursue political and social goals to the detriment of shareholder value (Fan et al., 2007; Wu et al., 2012). Political spending may be unprofitable investments which add no value to the firm (Ansolabehere et al., 2004; Hersch et al., 2008). On the flipside, Jayachandran (2006) suggests that firms target their contributions towards politicians with interests aligned to theirs. This ensures that when elected, the politician invariably pursues the interests of the firm. In federal agency rule making, firms comment and petition so as to make their policy preferences known to regulators and policymakers, and in order to avoid litigations agencies revise policy to suit the majority commenters (McKay \& Webb-Yackee, 2007). Politicians on corporate boards may extract rent from firms (Carretta et al., 2012) or extend government rents to firms (Hillman, 2005). The entry of business executives into politics is motivated by several reasons which include the alignment of interests and rent extraction (Bunkanwanicha \& Wiwattanakantang, 2009).

Majority of the studies in emerging and transition economies point to cronyism and favouritism (Johnson \& Mitton, 2003) and corruption (Khwaja \& Mian, 2005) as mechanisms through which political connections affect firm performance. Faccio et al. (2006) found that the value of political ties is higher in corrupt countries. Similarly, Fisman (2001) argue that corruption influences the size of political rents. Poor institutional development results in weak systems of checks and balances (Bunkanwanicha \& Wiwattanakantang, 2009) and the 
prevalence of relationship-based capital systems (Fraser et al., 2006) which allow for private benefits to be obtained. In China where the government controls many aspects of the stock market (Francis et al., 2009) and allocates resources (Peng \& Luo, 2000), there is incentive for preferential treatment to be accorded to politically connected firms (Wu et al., 2012; Yeh et al., 2013). Institutional theory thus underlies most of the CPA studies in developing countries.

Resource dependency posits that firms co-opt external dependencies in order to reduce uncertainty (Hillman, 2005). However, the resource dependence logic adopted by the literature to explain the mechanism through which CPA impacts performance includes another element. Here, the focus is on coercion or the yielding of other market actors to the demands of politically connected firms. The dependence of other market actors on government makes them yield to political pressures and extend favourable treatment to politically connected firms (Faccio et al., 2006). In a study of Pakistani banks, Khwaja and Mian (2005) argue that politicians are able to threaten bank officials with transfers, removals, or promotions if they do not yield to their demands. This institutional lapse coupled with corruption makes politically connected firms have their way with regards to preferential lending (Claessens et al., 2008) and low or no collaterals (Yeh et al., 2013). Interestingly, risk reduction is also a mechanism which determines CPA outcomes. Bliss and Gul (2012) argue that politically connected firms are charged higher interest rates due to their perceived riskiness. This finding is corroborated by Fraser at al. (2006) and Claessens et al. (2008) who found that connected firms carry more debt. High leverage increases financial distress and the risk of bankruptcy, hence higher interest rates on loans (Bliss \& Gul, 2012). 


\section{Discussion}

We find that CPA adds value to firms. It improves stock and operating performance (Claessens et al., 2008) and influences policy outcomes (McKay \& Webb-Yackee, 2007). Indeed, the context within which CPA is done or investigated seems to have an impact on the choice of strategy. First, financial strategies involving PAC and "soft money" contributions are dominant in the United States. Only a few countries in the world, obviously the developed ones, have laws which require that information about donations to political parties and candidates are made public (Claessens et al., 2008). All the studies which investigate financial strategies are based on United States data with the exception of one (Claessens et al., 2008) which is focused on campaign contributions in Brazil. It needs mentioning that Brazil is one of those few countries that have laws governing campaign finance.

In countries with strong legal systems where laws are enacted to guide and control political activity, it is relatively easier to observe and gather information on campaign contributions. Similarly, in countries where there are laws that govern the rulemaking process, it is easier to investigate information strategies. As noted by McKay and Webb-Yackee (2007) for the United States, the Administrative Procedure Act of 1946 requires all agencies to publicly publish proposed rules and solicit comments from the public before adopting them. This "notice and comment" window (McKay \& Webb-Yackee, 2007) provides opportunity for firms to influence the final rules (Lo, 2003). On the flip side, such regulations barely exist in countries with weak legal systems and this makes it difficult or impossible for firms to use or for researchers to study informational strategies in those contexts. It is therefore plausible to argue that financial and informational strategies are impacted by the level of institutional development. 
The external environment should stipulate the governance codes of practice to which firms must adhere. After all, it is the institutions of the state that moderate the economy (North, 1990). In emerging or developing countries however, the political institutions have not developed well enough to regulate most aspects of the economy, especially the interactions between business, government, regulators and the judiciary system. As a result, political strategies such as campaign financing and lobbying are not supervised, formalized, or institutionalized as we see in developed countries. Without laws governing campaign financing and lobbying, the ethicality of CPA becomes questionable. Research has shown that legality and transparency are requirements for ethical political behaviours (Gao, 2008; Oberman, 2004; Weber, 1997). Even though MNEs are able to play political roles by protecting human rights in repressive countries (Crane \& Matten, 2007) and reducing social ills such as disease and illiteracy (Margolis \& Walsh, 2003), they face daunting challenges of ensuring ethical political engagement. They need to reduce their political risk exposure in emerging countries through CPA, but they also need to gain legitimacy and be perceived as ethical even when there are no laws regulating political activity. MNEs therefore need to be careful in the governance of their political activity in emerging countries.

Campaign finance is an important strategy, but relational strategies are perhaps more important from our review. We find more studies have explored this nonmarket strategy in many different geographical contexts, from developing to developed countries, emerging to industrialized countries, and capitalist to transition economies. Whilst these strategies are common across the globe, they are more prevalent in emerging countries where institutional development is weak and fragile (Wu \& Cheng, 2011). The ease with which rents can be extracted from political patronage in emerging countries encourages business owners to enter politics or firms to connect with politicians for private benefits (Bunkanwanicha \& Wiwattanakantang, 2009; Fraser et al., 2006; Hassan et al., 2012; Imai, 2006). Wu and Cheng 
(2011) argue that political connections play a much more important role in emerging markets than in developed markets due to the existence of institutional voids in the former (Khanna \& Palepu, 2000).

In China which is an emerging and transition country, the government plays an important role in resource allocation (Peng \& Luo, 2000). Owing to the enormous influence of central governments and their unpredictability, firms establish relationships to manage the risk (Hillman et al., 1999) and to gain access to government controlled resources (Wu \& Cheng, 2011). The literature also cites that political connections, formal and informal, are more prevalent in "relationship-based capitalisms" (Fraser et al., 2006) where cronyism and personal relationships determine the allocation of capital resources (Johnson \& Mitton, 2003). Malaysia (Adhikari et al., 2006; Bliss \& Gul, 2012) and China (Sun et al., 2011) are the commonly tagged relationship-based economies. MNEs need to understand that in the absence of market supporting structures, social capital underpins the political and economic transactions in emerging countries (Peng \& Luo, 2000). Hence, the development and nurturing of personal level political ties suits this context, but as mentioned earlier the challenge comes from public reaction to such connections which are largely fraught in corruption.

\section{$<$ Insert Figure 2>}

Drawing on the IB literature above, we develop Figure 2 to show the different context variations and strategies. Indeed, there seems to be a connection between context and firm performance outcomes. Majority of the studies focused on Asia argue that CPA improves firm performance. However, two studies (Bliss \& Gul, 2012; Fan et al., 2007) reported a negative impact of CPA on performance in Malaysia and China. Similarly two studies (Aggarwal et al., 2011; Hadani \& Schuler, 2013) reported negative outcomes of CPA in the 
United States. Two other studies (Ansolabehere et al., 2004; Hersch et al., 2008) found no significant impact. In Italy found that political connections have a negative impact on bank performance (Carretta et al., 2012). In Brazil however, Claessens et al. (2008) found that campaign contributions positively impact stock and operating performances. Going by the statistics, a larger proportion of studies in developed countries reported negative or insignificant results. The few negative findings in emerging countries could be attributed to the loose definitions of political connections by the studies. In developed countries, the connections are usually defined by board membership which is typically deeply embedded in the fabric of the firms. However, in emerging countries the definition is often loose and extends to relations of politicians. In reality, the farther the political connection is away from the nexus of political power, the poorer the benefits (Khwaja \& Mian, 2005).

The mixed findings across different countries suggest that institutional characteristics could have a bearing on CPA outcomes. Multiple-country studies report evidence to support this claim. In countries with limited stock market development, fragile democracies, high corruption, and controlled press, there are better opportunities for CPA to yield substantive gains (Boubakri et al., 2012). MNEs in developing countries should therefore have the imperative to develop their political capabilities for two obvious reasons - risk reduction and superior competitive advantage. In deciding where to expand or the destination of foreign direct investment, MNEs may consider countries which receive assistance from The World Bank and the International Monetary Fund. The likelihood of government bailout in such countries (Faccio et al., 2006) may not extend to foreign firms, but this guarantee for the local firms reduces risk levels in the business environment and provides some insurance against any disruptions of the value chain.

Figure 3 shows the continental distribution of the reviewed literature, and the performance outcome directions (+ for positive; - for negative; O for no impact). 


\section{$<$ Insert Figure 3>}

Interestingly, all IB and economics based studies investigating policy performance found that CPA is able to influence policy decisions in ways favourable to the firm. For instance, contributions influence senate roll call vote (Liebman \& Reynolds, 2006; Mian, Sufi, \& Trebbi, 2010; Steagall \& Jennings, 1996) while political connections shape government subsidy decisions (Lee \& Baik, 2010; Wu \& Cheng, 2011) and protect firms from competition (Evans \& Sherlund, 2011). It is therefore plausible to argue based on the literature that informational strategies and any other strategies targeted at policy influence are usually successful. To prevent negative perceptions of corrupt corporate governance arising from unregulated campaign contributions in emerging countries, MNEs may develop deep knowledge of their business areas and create effective public affairs functions (Doh et al., 2014) capable of producing accurate and trustworthy petitions. Beside petitions being a formal procedure and hence posing no legitimacy risk, they are also mostly successful in influencing policy outcomes.

The contribution of this paper to IB scholarship is that institutional frameworks influence organizational behaviour and affect the strategic choices firms must make (North, 1990; Oliver, 1991; Peng, 2003; Suddaby, 2010), and in this case the CPA choices of MNEs. The central theme of this argument may resonate with institutional isomorphism whereby institutional forces compel firms to comply and seek homogeneity with existing conditions and other actors (DiMaggio \& Powell, 1983). For legitimacy reasons, MNEs may come under severe pressure to follow the rules and observe the norms in host countries (Scott, 2005), but they are also capable of acting as institutional entrepreneurs (DiMaggio, 1988) in developing countries where they can play global governance roles by transferring best principles and rules of political engagement from home to host country. Already, MNEs are playing key roles in ensuring human rights (Crane \& Matten, 2007; Scherer \& Palazzo, 2007). There is 
room for MNEs from home countries where CPA is regulated to push for similar laws in emerging countries. Countries such as the U.S, Germany, and U.K are homes to most of the MNEs which operate in developing countries. Rules of business-government relations and corporate citizenship (Moon et al., 2005) in these developed countries could be transferred to resolve the anarchical nature of political engagement in emerging countries. Experiences in their home countries could be brought to bear on the policy arena in developing countries.

\subsection{Mapping the CIMO-logic of CPA-Firm Performance}

Having teased out the themes of the CIMO-logic, it is time to bring it all together to derive the whole picture. More importantly, we define our contribution again, to show how we add to the CPA field and more broadly to the IB arena. Firstly, using the CIMO-logic, we show that the common strategy in developing countries is the relational strategy where firms establish connections with politicians, which can be a liability or an advantage. In developed countries, financial and informational strategies are popular. Perhaps, this is because developed countries have laws that regulate political spending and the policymaking process, allowing firms to participate in political and policy issues. Relational strategies affect performance outcomes mainly through the acquisition of social capital (Sun et al., 2011; Wu et al., 2012), the use of force (Khwaja \& Mian, 2005), the exploitation of institutional lapses or through corruption (Johnson \& Mitton, 2003). Note that these mechanisms are popular in relationship-based capital systems (Adhikari et al., 2006) where institutional development is weak. The pressure on other firms to yield to the demands of politicians and politically connected firms is much stronger in emerging countries (Faccio et al., 2006; Khwaja \& Mian, 2005). Owing to poor institutions, policy outcomes are not investigated in emerging countries. Firms in these countries have a little chance to influence the formulation of policy. In developed countries however, the presence of checks and balances reduces the probability of governments to exercise undue power over firms. Firms are given the opportunity to 
comment on proposals, green papers and white papers. Drawing on evidence from the literature, we capture the CIMO-logic of CPA in Figure 4.

\section{$<$ Insert Figure 4>}

The paucity of IB studies about informational strategies in emerging countries could be a sign that corporations are not doing much to leave footprints on the policy landscape. This could be the result of poor institutional development which makes it difficult for firms to participate in the policy process. However corporations, especially MNEs, will have to invoke their institutional entrepreneurship to positively prevail upon the fragile political institutions in emerging countries.

\section{Conclusion and Future Agenda}

In conclusion, the investigation of IB studies and other important studies in economics, finance and political science, on the relationship between CPA and firm performance reveals that there is a general view that CPA impacts firm performance positively. Going by the empirical evidence from this review, suffice to argue that the advocacy for nonmarket strategy (Baron, 1995) and CPA (Lawton et al., 2013) is justified. The findings corroborate other studies (Bonardi, Holburn, \& Bergh, 2006; Capron \& Chatain, 2008; McWilliams et al., 2002) which suggest that nonmarket action adds value to firms, and strengthens Bernhagen and Brauninger's (2005) the claim that policy decisions are positively skewed towards business interests. However, there are few studies which report evidence to the contrary (Bliss \& Gul, 2012; Fan et al., 2007; Hadani \& Schuler, 2013). It is therefore not surprising that our understanding of CPA outcomes remains incomplete and inconclusive (Hadani \& Schuler, 2013). 
What strikes clearly from the literature is the influence of context on the strategies used by firms and the type of outcomes CPA can achieve. In emerging countries, relational strategies are commonly used and the targeted outcomes are mostly operating and stock performances. Social capital from informal ties with politicians is about the most valuable political asset a firm can ever have in emerging countries. Policy change does not seem to be a feasible project for firms in developing countries where political institutions are yet to fully incorporate the opinions of the private sector in the policy making process. We understand that favours and preferential treatment often times result in corruption and cronyism (Imai, 2006; Johnson \& Mitton, 2003), but are the channels of superior performance for firms in these countries.

Our findings have implications for managers, especially those of MNEs. First, foreign firms in emerging countries face greater environmental risks (Puck et al., 2013) owing to the volatility and fragility of the institutions in these countries (Luo, 2004). According to Henisz and Zelner (2003), the absence of checks and balances in these countries make them high risk. Hence firms in these high risk environments would have to indulge in CPA to reduce their exposure to uncertainty (Meznar \& Nigh, 1995). However, not every strategy works in every institutional context. Similarly, not every outcome is easy or possible to achieve in every context. Relational strategies seem to work best in emerging countries, but more research needs to explore the liabilities of these networks over time. Social capital, with its attendant benefits, proves to be the value-adding resource in the developing world. Though policy may seem difficult to influence in emerging countries due to reasons already discussed earlier, firms which are able to get involved in the policy process are more likely to be successful. The difficulty would be access to the policy making machinery. On a general note, CPA improves performance. It is therefore worth it for managers of local firms and MNEs alike to invest in corporate political engagement. MNEs need to consider the 
institutional environment of host countries when deciding political engagement. They also need to strengthen their capabilities to act as institutional entrepreneurs in emerging countries where they can help develop the fragile institutions in these countries by transferring and advocating CPA best practices. Their contribution to global governance is as important as that of the Bretton-Woods institutions.

As much as the thematic analysis of the reviewed literature has improved our knowledge of the CPA-firm performance relationship, it has also facilitated the identification of gaps in the extant literature with respect to contexts, interventions/strategies, mechanisms, and outcomes of CPA. Consequently, we propose the following significant avenues for future research.

The CPA literature body is replete with studies on antecedents (Hansen \& Mitchell, 2000; Hersch \& McDougall, 2000; Hillman, 2003; Hillman et al., 2004; Lawton, Rajwani, \& Doh, 2013), strategies (Keim \& Zeithaml, 1986) and conceptions/theory (Boddewyn \& Brewer, 1994; Bonardi \& Keim, 2005; Bonardi, Hillman, \& Keim, 2005; Capron \& Chatain, 2008; Hillman \& Keim, 1995). However, the outcomes of CPA are among the least studied (Lux et al., 2011). There are many theories that explain why firms engage in CPA or why firms conduct CPA in particular ways (Getz, 1997), but only a few have been applied to explain CPA outcomes. One theory that is popular with research in emerging and developing countries is institutional theory. Evidence from this review suggests that the outcomes of CPA may vary with different institutional contexts (Hillman, 2005; Wu \& Cheng, 2011; Wu et al., 2012). Meanwhile a scrutiny of the geographic distribution of studies on the outcomes of CPA reveals that some regions, especially Australia and Africa, remain unexplored. Future studies could examine the impact of CPA on firm performance in Africa which has a unique institutional environment. In a similar vein, the impact of CPA on MNE performance in emerging and developing countries could be a significant avenue for future research. 
Studies do not examine financial and informational strategies in developing countries. Most of these strategies are focused on United States, except one study (Claessens et al., 2008) which examines political spending in Brazil. There are two possible explanations for this observation: 1) it could be the case that studies have intentionally or unintentionally overlooked these strategies in the emerging markets contexts or 2) these strategies are not used by firms in developing countries. It is however difficult to accept the latter since everywhere in the world corporations seem to play a role in politics. Following from that premise, we propose that future research could investigate financial and informational strategies in emerging countries but also what the antecedents of these strategies are and how they are deployed. If there is a view that these strategies are invisible or non-existent in the developing world context, future studies could explore how contextual or institutional configurations influence the choice of CPA strategies. As emerging countries promise to be attractive to IB scholars (Doh et al., 2012), this sort of focus would be useful for multinationals, especially in terms of market entry research.

While the linkage between context, strategies and performance outcomes are clear in the literature, the theoretical mechanisms through which these strategies exert their influence on firm performance outcomes are less clear. The explicit adoption of a theoretical framing for explaining the performance outcomes of CPA is largely missing. It therefore seems that the literature is biased about answering the "what" but not the "how" questions with respect to the outcomes of CPA. Explicating the mechanisms through which CPA affects firm performance will deepen understanding of the topic (Adhikari et al., 2006; Dean, Vryza, \& Fryxell, 1998; Hillman et al., 1999), but this is missed by the literatures. Thus, future IB studies could fill this gap using multiple indicators to better understand outcomes.

The outcomes of CPA have been measured in very different ways. Most studies examine stock performance (Cooper et al., 2010; Goldman et al., 2009; Huber \& Kirchler, 2013) and 
operating performance (Carretta et al., 2012; Chaney et al., 2011; Claessens et al., 2008). There are some others which examine academic earmarks (De Figueiredo \& Silverman, 2006), anti-dumping proceeds (Lee \& Baik, 2010), government contracts (Witko, 2011), bailouts (Faccio et al., 2006), trade mission participation (Schuler et al., 2002) and regulations (McKay \& Webb-Yackee, 2007). It is thus evident that CPA outcomes have been examined using different variables and constructs, but there is still room for the impact of CPA on other performance metrics to be investigated (Lux et al., 2011). Future studies could examine how CPA impacts restrictions on pricing or mark ups and import or export licensing. Future studies could also examine industry entry restrictions by measuring how long it takes MNEs to obtain operating licenses.

Our review also reveals that empirical studies address corporate involvement in the political process mainly at the national level. While it is at this level that most of CPA can be seen, it still does not rule out the fact that CPA exists at the local/regional/state/supranational levels. For instance, in the United States majority of the studies focus on national politics to the neglect of State politics, yet State governments have authority to enact laws and pass regulations which can affect different types of firms. Similarly in developing countries, local governments have the authority to set tolls and tax rates. These instances also highlight a significant research opportunity to investigate the CPA of small firms which may not have the resources or capabilities to participate in national-level politics. They may use other forms of nepotism to influence governments for grants or tax benefits.

Finally, surveys are used less in CPA empirical studies. In this review, only two studies (Lu, 2011; Peng \& Luo, 2000) use this approach. While surveys could be used to obtain unique datasets for unique constructs, they could also be used to collect information which is not public. Outside this review, we have found recent work by White et al. (2014) who use these techniques effectively. Drawing on their ideas, future researchers could use more of these 
survey techniques in ways that allow for novel constructs to be developed at a multi-level i.e. CPA performance constructs like 'perceived performance' at individual, team, business unit and organizational levels in parallel to regional, national and international levels. Indeed, the CPA field and theories in this growing domain have fruitful research opportunities. We hope our ideas shed light on them for future IB scholars, especially as this world becomes more multi-polar in terms of power shifts from west to east. 


\section{References}

Adhikari, A., Derashid, C., \& Zhang, H. (2006). Public policy, political connections, and effective tax rates: Longitudinal evidence from Malaysia. Journal of Accounting \& Public Policy, 25(5), 574-595.

Aggarwal, R. K., Meschke, F., \& Wang, T. Y. (2011). Corporate political donations: Investment or agency? Business \& Politics, 14(1), 1649-3569.

Alzola, M. (2013). Corporate dystopia: The ethics of corporate political spending. Business \& Society, 52(3), 388-426.

Amore, M. D., \& Bennedsen, M. (2013). The value of local political connections in a lowcorruption environment. Journal of Financial Economics, 110(2), 387-402.

Anderson, S., Allen, P., Peckham, S., \& Goodwin, N. (2008). Asking the right questions: Scoping studies in the commissioning of research on the organisation and delivery of health services. Health Research Policy \& Systems, 6, 1-12.

Ansolabehere, S. D., Synder, J. M., \& Ueda, M. (2004). Did firms profit from soft money? Election Law Journal, 3(2), 193-198.

Ansolabehere, S., Snyder Jr, J. M., \& Tripathi, M. (2002). Are PAC contributions and lobbying linked? New evidence from the 1995 lobby disclosure act. Business \& Politics, 4(2), 131-155.

Arksey, H., \& O'malley, L. (2005). Scoping studies: Towards a methodological framework. International Journal of Social Research Methodology, 8(1), 19-32.

Barney, J. (1991). Firm resources and sustained competitive advantage. Journal of Management, 17(1), 99-120.

Baron, D. P. (1995). Integrated strategy: Market and nonmarket components. California Management Review, 37(2), 47-65.

Barron, A. (2011). Exploring national culture's consequences on international business lobbying. Journal of World Business, 46(3), 320-327.

Bernhagen, P., \& Brauninger, T. (2005). Structural power and public policy: A signaling model of business lobbying in democratic capitalism. Political Studies, 53(1), 43-64.

Bliss, M. A., \& Gul, F. A. (2012). Political connection and cost of debt: Some Malaysian evidence. Journal of Banking \& Finance, 36(5), 1520-1527.

Blumentritt, T. P. (2003). Foreign subsidiaries' government affairs activities: The influence of managers and resources. Business and Society, 42(2), 202-233. 
Boddewyn, J. J., \& Brewer, T. L. (1994). International-business political behavior: New theoretical directions. Academy of Management Review, 19(1), 119-143.

Bonardi, J., \& Keim, G. D. (2005). Corporate political strategies for widely salient issues. Academy of Management Review, 30(3), 555-576.

Bonardi, J., Hillman, A. J., \& Keim, G. D. (2005). The attractiveness of political markets: Implications for firm strategy. Academy of Management Review, 30(2), 397-413.

Bonardi, J., Holburn, G. L. F., \& Bergh, R. G. V. (2006). Nonmarket strategy performance: Evidence from U.S. electric utilities. The Academy of Management Journal, 49(6), 12091228.

Boubakri, N., Cosset, J., \& Saffar, W. (2008). Political connections of newly privatized firms. Journal of Corporate Finance, 14(5), 654-673.

Boubakri, N., Cosset, J., \& Saffar, W. (2012). The impact of political connections on firms' operating performance and financing decisions. Journal of Financial Research, 35(3), 397-423.

Boubakri, N., Guedhami, O., Mishra, D., \& Saffar, W. (2012). Political connections and the cost of equity capital. Journal of Corporate Finance, 18(3), 541-559.

Brown, W. (1996). Friends in high places: The wealth effects of JFK's assassination on the assets of LBJ's supporters. Public Choice (1986-1998), 86(3-4), 247-256.

Bunkanwanicha, P., \& Wiwattanakantang, Y. (2009). Big business owners in politics. Review of Financial Studies, 22(6), 2133-2168.

Capron, L., \& Chatain, O. (2008). Competitors' resource-oriented strategies: Acting on competitors' resources through interventions in factor markets and political markets. Academy of Management Review, 33(1), 97-121.

Carretta, A., Farina, V., Gon, A., \& Parisi, A. (2012). Politicians 'on board': Do political connections affect banking activities in Italy? European Management Review, 9(2), 7583.

Chaney, P. K., Faccio, M., \& Parsley, D. (2011). The quality of accounting information in politically connected firms. Journal of Accounting \& Economics, 51(1-2), 58-76.

Chen, Y. R. (2007). The strategic management of government affairs in china: How multinational corporations in china interact with the Chinese government. Journal of Public Relations Research, 19(3), 283-306.

Claessens, S., Feijen, E., \& Laeven, L. (2008). Political connections and preferential access to finance: The role of campaign contributions. Journal of Financial Economics, 88(3), 554-580. 
Cooper, M. J., Gulen, H., \& Ovtchinnikov, A. V. (2010). Corporate political contributions and stock returns. Journal of Finance, 65(2), 687-724.

Crane, A., \& Matten, D. (2007). Business ethics: Managing corporate citizenship and sustainability in the age of globalization. New York: Oxford University Press

De Figueiredo, J. M., \& Silverman, B. S. (2006). Academic earmarks and the returns to lobbying. Journal of Law and Economics, 49, 597-626.

De Menezes, L. M., \& Kelliher, C. (2011). Flexible working and performance: A systematic review of the evidence for a business case. International Journal of Management Reviews, 13(4), 452-474.

Dean, T., Vryza, M., \& Fryxell, G. E. (1998). Do corporate PACs restrict competition? an empirical examination of industry PAC contributions and entry. Business and Society, $37(2), 135-156$.

Denyer, D., Tranfield, D., \& van Aken, J. (2008). Developing design propositions through research synthesis. Organization Studies, 29(3), 393-413.

DiMaggio, P. J. (1988). Interest and agency in institutional theory. In L. Zucker (Ed.), Institutional patterns and culture (pp. 3-22). Cambridge, MA: Ballinger Publishing Company.

DiMaggio, P. J., \& Powell, W. W. (1983). The iron cage revisited: Institutional isomorphism and collective rationality in organizational fields. American Sociological Review, 48, 147-160.

Doh, J. P., Lawton, T. C., \& Rajwani, T. (2012). Advancing nonmarket strategy research: Institutional perspectives in a changing world. Academy of Management Perspectives, 26(3), 22-39.

Doh, J., Lawton, T., Rajwani, T., \& Paroutis, S. (2014). Why your company may need a chief external officer: Upgrading external affairs can help align strategy and improve competitive advantage. Organization Dynamics, Forthcoming

Evans, C. L., \& Sherlund, S. M. (2011). Are antidumping duties for sale? case-level evidence on the Grossman-Helpman protection for sale model. Southern Economic Journal, 78(2), 330-357.

Faccio, M. (2006). Politically connected firms. American Economic Review, 96(1), 369-386.

Faccio, M., Masulis, R. W., \& McConnell, J. J. (2006). Political connections and corporate bailouts. Journal of Finance, 61(6), 2597-2635.

Fan, J. P. H., Wong, T. J., \& Zhang, T. (2007). Politically connected CEOs, corporate governance, and post-IPO performance of China's newly partially privatized firms. Journal of Financial Economics, 84(2), 330-357. 
Fisman, R. (2001). Estimating the value of political connections. American Economic Review, 91(4), 1095-1102.

Francis, B. B., Hasan, I., \& Sun, X. (2009). Political connections and the process of going public: Evidence from China. Journal of International Money \& Finance, 28(4), 696719.

Fraser, D. R., Zhang, H., \& Derashid, C. (2006). Capital structure and political patronage: The case of Malaysia. Journal of Banking \& Finance, 30(4), 1291-1308.

Frynas, J. G., \& Mellahi, K. (2003). Political risks as firm-specific (dis)advantages: Evidence on transnational oil firms in Nigeria. Thunderbird International Business Review, 45(5), 541-565.

Gao, Y. (2008). An ethical judgment framework for corporate political actions. Journal of Public Affairs, 8(3), 153-163.

Getz, K. A. (1997). Research in corporate political action. Business \& Society, 36(1), 32-72.

Goldman, E., Rocholl, J., \& So, J. (2009). Do politically connected boards affect firm value? The Review of Financial Studies, 22(6), 2331-2360.

Grant, M. J., \& Booth, A. (2009). A typology of reviews: An analysis of 14 review types and associated methodologies. Health Information \& Libraries Journal, 26(2), 91-108.

Grier, K. B., Munger, M. C., \& Roberts, B. E. (1994). The determinants of industry political activity, 1978-1986. American Political Science Review, 88(4), 911-926.

Griffin, J. J., \& Dunn, P. (2004). Corporate public affairs: Commitment, resources, and structure. Business \& Society, 43(2), 196-220.

Hadani, M., \& Schuler, D. A. (2013). In search of el dorado: The elusive financial returns on corporate political investments. Strategic Management Journal, 34(2), 165-181.

Hansen, W. L., \& Mitchell, N. J. (2000). Disaggregating and explaining corporate political activity: Domestic and foreign corporations in national politics. American Political Science Review, 94(4), 891-903.

Hassan, T., Hassan, M. K., Mohamad, S., \& Min, C. C. (2012). Political patronage and firm performance: Further evidence from Malaysia. Thunderbird International Business Review, 54(3), 373-393.

Henisz, W. J. (2004). Political institutions and policy volatility. Economics \& Politics, 16(1), $1-27$.

Henisz, W. J., \& Zelner, B. A. (2003). The strategic organization of political risks and opportunities. Strategic Organization, 1(4), 451-460. 
Henisz, W. J., \& Zelner, B. A. (2010). The hidden risks in emerging markets. Harvard Business Review, 88(4), 88-95.

Hersch, P. L., \& McDougall, G. S. (2000). Determinants of automobile PAC contributions to house incumbents: Own versus rival effects. Public Choice, 104(3-4), 329-343.

Hersch, P., Netter, J. M., \& Pope, C. (2008). Do campaign contributions and lobbying expenditures by firms create "Political" capital? Atlantic Economic Journal, 36(4), 395405.

Hillman, A. J. (2003). Determinants of political strategies in US. multinationals. Business \& Society, 42(4), 455-484.

Hillman, A. J. (2005). Politicians on the board of directors: Do connections affect the bottom line? Journal of Management, 31(3), 464-481.

Hillman, A. J., \& Hitt, M. A. (1999). Corporate political strategy formulation: A model of approach, participation, and strategy decisions. Academy of Management Review, 24(4), 825-842.

Hillman, A. J., \& Wan, W. P. (2005). The determinants of MNE subsidiaries' political strategies: Evidence of institutional duality. Journal of International Business Studies, $36(3), 322-340$.

Hillman, A. J., Keim, G. D., \& Schuler, D. (2004). Corporate political activity: A review and research agenda. Journal of Management, 30(6), 837-857.

Hillman, A. J., Zardkoohi, A., \& Bierman, L. (1999). Corporate political strategies and firm performance: Indications of firm specific benefits from personal service in the US government. Strategic Management Journal, 20, 67-81.

Hillman, A., \& Keim, G. (1995). International variation in the business-government interface: Institutional and organizational considerations. Academy of Management Review, 20(1), 193-214.

Holmes, M., Miller., T, Hitt, M and Salmador, M.P. (2013). The Interrelationships among Informal Institutions, Formal Institutions and Inward Foreign Direct Investment. Journal of Management, 2013, 39(2), 531-566.

Holburn, G. L. F., \& Vanden Bergh, R. (2008). Making friends in hostile environments: Political strategy in regulated industries. Academy of Management Review, 33(2), 521540.

Huber, J., \& Kirchler, M. (2013). Corporate campaign contributions and abnormal stock returns after presidential elections. Public Choice, 156(1), 285-307.

Imai, M. (2006). Mixing family business with politics in Thailand. Asian Economic Journal, 20(3), 241-256. 
Jayachandran, S. (2006). The jeffords effect. Journal of Law and Economics, 49(2), 397-425.

Jensen, M., \& Meckling, W. H. (1976). Theory of the firm: Managerial behavior, agency costs and ownership structure. Journal of Financial Economics, 3(4), 305-360.

Johnson, S., \& Mitton, T. (2003). Cronyism and capital controls: Evidence from Malaysia. Journal of Financial Economics, 67(2), 351-382.

Keillor, B. D., Wilkinson, T. J., \& Owens, D. (2005). Threats to international operations: Dealing with political risk at the firm level. Journal of Business Research, 58(5), 629635.

Keim, G. D., \& Zeithaml, C. P. (1986). Corporate political strategy and legislative decision making: A review and contingency approach. Academy of Management Review, 11(4), 828-843.

Khanna, T., \& Palepu, K. (2000). The future of business groups in emerging markets: Longrun evidence from Chile. Academy of Management Journal, 43(3), 268-285.

Khwaja, A. I., \& Mian, A. (2005). Do lenders favour politically connected firms? rent provision in an emerging financial market. The Quarterly Journal of Economics, 120(4), 1371-1411.

Kim, J. (2008). Corporate lobbying revisited. Business \& Politics, 10(2), 1-23.

Lawton, T., McGuire, S., \& Rajwani, T. (2013). Corporate political activity: A literature review and research agenda. International Journal of Management Reviews, 15(1), 86105.

Lawton, T., Rajwani, T., \& Doh, J. (2013). The antecedents of political capabilities: A study of ownership, cross-border activity and organization at legacy airlines in a deregulatory context. International Business Review, 22(1), 228-242.

Lawton, T., Doh, J., \& Rajwani, T. (2014). Aligning for Advantage: Competitive strategies for political and social arenas, Oxford University Press.

Lee, S., \& Baik, Y. (2010). Corporate lobbying in antidumping cases: Looking into the continued dumping and subsidy offset act. Journal of Business Ethics, 96(3), 467-478.

Leuz, C., \& Oberholzer-Gee, F. (2006). Political relationships, global financing, and corporate transparency: Evidence from indonesia. Journal of Financial Economics, 81(2), 411-439.

Levac, D., Colquhoun, H., \& O'Brien, K. K. (2010). Scoping studies: Advancing the methodology. Implementation Science, 5, 69-77.

Liebman, B. H., \& Reynolds, K. M. (2006). The returns from rent seeking: Campaign contributions, firm subsidies and byrd amendment. Canadian Journal of Economics, 39(4), 1345-1369. 
Lo, K. (2003). Economic consequences of regulated changes in disclosure: The case of executive compensation. Journal of Accounting \& Economics, 35(3), 285-314.

Lu, Y. (2011). Political connections and trade expansion. Economics of Transition, 19(2), 231-254.

Luo, Y. (2004). Building a strong foothold in an emerging market: A link between resource commitment and environment conditions. Journal of Management Studies, 41(5), 749773.

Luo, Y., \& Zhao, H. (2013). Doing business in a transitional society: Economic environment and relational political strategy for multinationals. Business \& Society, 52(3), 515-549.

Lux, S., Crook, T. R., \& Woehr, D. J. (2011). Mixing business with politics: A meta-analysis of the antecedents and outcomes of corporate political activity. Journal of Management, $37(1), 223-247$.

Margolis, J. D., \& Walsh, J. P. (2003). Misery loves companies: Rethinking social initiatives by business. Administrative Science Quarterly, 48(2), 268-305.

Marsh, S. (1998). Creating barriers for foreign competitors: A study of the impact of antidumping actions on the performance of US firms. Strategic Management Journal, 19(1), 25-37.

Mathur, I., \& Singh, M. (2011). Corporate political strategies. Accounting \& Finance, 51(1), 252-277.

Matten, D., \& Crane, A. (2005). Corporate citizenship: Toward an extended theoretical conceptualization. Academy of Management Review, 30(1), 166-179.

McGuire, J., Schneeweis, T., \& Naroff, J. (1988). Effects of top managers cabinet appointments on shareholder's wealth. Academy of Management Journal, 31(1), 201212.

McKay, A., \& Webb-Yackee, S. (2007). Interest group competition on federal agency rules. American Politics Research, 35(3), 336-357.

McWilliams, A., Van Fleet, D. D., \& Cory, K. D. (2002). Raising rivals' costs through political strategy: An extension of resource-based theory. Journal of Management Studies, 39(5), 707-723.

Meznar, M. B., \& Nigh, D. (1995). Buffer or bridge? environmental and organizational determinants of public affairs activities in American firms. The Academy of Management Journal, 38(4), 975-996.

Mian, A., Sufi, A., \& Trebbi, F. (2010). The political economy of the US mortgage default crisis. American Economic Review, 100(5), 1967-1998. 
Moon, J., Crane, A., \& Matten, D. (2005). Can corporations be citizens? Corporate citizenship as a metaphor for business participation in society. Business Ethics Quarterly, 15(3), 429-453.

Neron, P. Y., \& Norman, W. (2008). Citizenship, inc.: Do we really want businesses to be good corporate citizens? Business Ethics Quarterly, 18(1), 1-26.

Niessen, A., \& Ruenzi, S. (2010). Political connectedness and firm performance: Evidence from Germany. German Economic Review, 11(4), 441-464.

North, D. C. (1990). Institutions, institutional change and economic performance Cambridge: Cambridge University Press, 1990.

Oberman, W. D. (2004). A framework for the ethical analysis of corporate political activity. Business \& Society Review, 109(2), 245-262.

Okhmatovskiy, I. (2010). Performance implications of ties to the government and SOEs: A political embeddedness perspective. Journal of Management Studies, 47(6), 1020-1047.

Oliver, C. (1991). Strategic responses to institutional processes. Academy of Management Review, 16(1), 145-179.

Peng, M. W. (2003). Institutional transitions and strategic choices. The Academy of Management Review, 28(2), 275-296.

Peng, M. W., \& Luo, Y. (2000). Managerial ties and firm performance in a transition economy: The nature of a micro-macro link. The Academy of Management Journal, 43(3), 486-501.

Petticrew, M., \& Roberts, H. (2006). Systematic reviews in the social sciences: A practical guide Oxford: Blackwell.

Pfeffer, J., \& Salancik, G. R. (1978). The external control of organizations. New York: Harper and Row.

Pilbeam, C., Alvarez, G., \& Wilson, H. (2012). The governance of supply networks: A systematic literature review. Supply Chain Management, 17(4), 358-376.

Pittaway, L., Robertson, M., Munir, K., Denyer, D., \& Neely, A. (2004). Networking and innovation: A systematic review of the evidence. International Journal of Management Reviews, 5/6(3), 137-168.

Puck, J. F., Rogers, H., \& Mohr, A. T. (2013). Flying under the radar: Foreign firm visibility and the efficacy of political strategies in emerging economies. International Business Review, 22(6), 1021-1033.

Richter, B. K., Samphantharak, K., \& Timmons, J. F. (2009). Lobbying and taxes. American Journal of Political Science, 53(4), 893-909. 
Roberts, B. E. (1990). A dead senator tells no lies: Seniority and the distribution of federal benefits. American Journal of Political Science, 34(1), 31-58.

Schuler, D. A. (1996). Corporate political strategy and foreign competition: The case of the steel industry. Academy of Management Journal, 39(3), 720-737.

Schuler, D. A., Rehbein, K., \& Cramer, R. D. (2002). Pursuing strategic advantage through political means: A multivariate approach. Academy of Management Journal, 45(4), 659672.

Schuler, D. A., Schnietz, K. E., \& Baggett, L. S. (2002). Determinants of foreign trade mission participation: An analysis of corporate political and trade activities. Business \& Society, 41(1), 6-35.

Scott, W. R. (2005). Institutional theory: Contributing to a theoretical research program. In K. G. Smith, \& M. A. Hitt (Eds.), Great minds in Management: The process of theory development (pp. 460-484). Oxford: Oxford University Press.

Steagall, J. W., \& Jennings, K. (1996). Unions, PAC contributions, and the NAFTA vote. Journal of Labor Research, 17(3), 515-521.

Stigler, G. (1971). The theory of economic regulation. Bell Journal of Economics and Management Science, 2(1), 3-21.

Sun, P., Mellahi, K., \& Thun, E. (2010). The dynamic value of MNE political embeddedness: The case of the Chinese automobile industry. Journal of International Business Studies, 41(7), 1161-1182.

Sun, P., Xu, H., \& Zhou, J. (2011). The value of local political capital in transition china. Economics Letters, 110(3), 189-192.

Tranfield, D., Denyer, D., \& Smart, P. (2003). Towards a methodology for developing evidence-informed management knowledge by means of systematic review. British Journal of Management, 14(3), 207-222.

Tu, G., Lin, B., \& Liu, F. (2013). Political connections and privatization: Evidence from china. Journal of Accounting and Public Policy, 32(2), 114-135.

White, G. O., Joplin, J. R.W., Hemphill, T. A., \& Marsh, L. (2014). Wholly owned foreign subsidiary relation-based strategies in volatile emerging market environments. International Business Review. Forthcoming.

Williamson, O. E. (1985). The economic institutions of capitalism: Firms, markets, relational contracting New York: Free Press.

Witko, C. (2011). Campaign contributions, access, and government contracting. Journal of Public Administration Research and Theory, 21(4), 761-778. 
Worrell, D. L., \& Davidson III, W. N. (1987). The effect of CEO succession on stockholder wealth in large firms following the death of the predecessor. Journal of Management, 13(3), 509-515.

Wu, J., \& Cheng, M. L. (2011). The impact of managerial political connections and quality on government subsidies. Chinese Management Studies, 5(2), 207-226.

Wu, W., Wu, C., \& Rui, O. M. (2012). Ownership and the value of political connections: Evidence from China. European Financial Management, 18(4), 695-729.

Wu, W., Wu, C., Zhou, C., \& Wu, J. (2012). Political connections, tax benefits and firm performance: Evidence from china. Journal of Accounting \& Public Policy, 31(3), $277-$ 300.

Yeh, Y., Shu, P., \& Chiu, S. (2013). Political connections, corporate governance and preferential bank loans. Pacific-Basin Finance Journal, 21(1), 1079-1101. 


\section{Appendices}

\section{Appendix A: Quality Appraisal Tool}

\begin{tabular}{|c|c|}
\hline Code & Criteria \\
\hline & Theoretical framework and development of hypotheses \\
\hline $\mathbf{A}$ & Are the study's propositions and hypotheses clearly articulated? \\
\hline B & Are the basic arguments of the paper important and interesting? \\
\hline $\mathbf{C}$ & Are important premises and assumptions identified? \\
\hline \multirow[t]{2}{*}{$\mathbf{D}$} & Are the key terms defined? \\
\hline & Description and evaluation of methods \\
\hline $\mathbf{E}$ & Is the methodology of the paper clearly identified? \\
\hline $\mathbf{F}$ & Are data collection methods described adequately? \\
\hline $\mathbf{G}$ & Are the sampling strategy and sample explained? \\
\hline $\mathbf{H}$ & Is the operationalization of the variables and the constructs plausible (content validity)? \\
\hline I & Are dependent and control variables identified and described? \\
\hline $\mathbf{J}$ & Do measures theoretically relate to independent and dependent variables (construct validity)? \\
\hline $\mathbf{K}$ & Are questionnaire or other instrument items identified and described? \\
\hline $\mathbf{L}$ & Have steps been taken to avoid data collection errors? \\
\hline \multirow[t]{2}{*}{ M } & Is there evidence of reliability or internal consistency in the study? \\
\hline & Results \\
\hline $\mathbf{N}$ & Are the findings adequately and accurately described? \\
\hline $\mathbf{O}$ & $\begin{array}{l}\text { Are the results related back to original propositions, hypothesis, research question, and data } \\
\text { analysis? }\end{array}$ \\
\hline $\mathbf{P}$ & $\begin{array}{l}\text { Do tables provide sufficient and accurate data to allow reader to reach independent } \\
\text { conclusions? }\end{array}$ \\
\hline $\mathbf{Q}$ & Is implied causality justified? \\
\hline $\mathbf{R}$ & Has the author adequately considered alternative explanations for the results? \\
\hline
\end{tabular}




\section{Appendix B: List of Selected Studies}

\begin{tabular}{|c|c|c|c|c|c|}
\hline No & Study & No & Study & No & Study \\
\hline 1 & Adhikari et al. (2006) & 21 & Francis et al. (2009) & 41 & Mathur and Singh (2011) \\
\hline 2 & Aggarwal et al. (2011) & 22 & Fraser et al. (2006) & 42 & McGuire et al. (1988) \\
\hline 3 & Ansolabehere et al. (2004) & 23 & Goldman et al. (2009) & 43 & $\begin{array}{l}\text { McKay and Webb- } \\
\text { Yackee (2007) }\end{array}$ \\
\hline 4 & Bliss and Gul (2012) & 24 & $\begin{array}{l}\text { Hadani and Schuler } \\
\text { (2013) }\end{array}$ & 44 & Mian et al. (2010) \\
\hline 5 & Boubakri et al. (2012) & 25 & Hassan et al. (2012) & 45 & $\begin{array}{l}\text { Niessen and Ruenzi } \\
(2010)\end{array}$ \\
\hline 6 & Boubakri et al. (2008) & 26 & Hersch et al. (2008) & 46 & Peng and Luo (2000) \\
\hline 7 & Boubakri et al. (2012) & 27 & Hillman et al. (1999) & 47 & Richter et al. (2009) \\
\hline 8 & Brown (1996) & 28 & Hillman (2005) & 48 & Schuler et al. (2002) \\
\hline 9 & $\begin{array}{l}\text { Bunkanwanicha and } \\
\text { Wiwattanakantang (2009) }\end{array}$ & 29 & $\begin{array}{l}\text { Huber and Kirchler } \\
(2013)\end{array}$ & 49 & $\begin{array}{l}\text { Steagall and Jennings } \\
(1996)\end{array}$ \\
\hline 10 & Carretta et al. (2012) & 30 & Imai (2006) & 50 & Sun et al. (2011) \\
\hline 11 & Chaney et al. (2011) & 31 & Jayachandran (2006) & 51 & Tu et al. (2013) \\
\hline 12 & Claessens et al. (2008) & 32 & $\begin{array}{l}\text { Johnson and Mitton } \\
(2003)\end{array}$ & 52 & Witko (2011) \\
\hline 13 & Cooper et al. (2010) & 33 & Khwaja and Mian (2005) & 53 & Wu and Cheng (2011) \\
\hline 14 & $\begin{array}{l}\text { de Figueiredo and Silverman } \\
(2006)\end{array}$ & 34 & Kim (2008) & 54 & Wu et al. (2012) \\
\hline 15 & Dean et al. (1998) & 35 & Lee and Baik (2010) & 55 & Wu et al. (2012) \\
\hline 16 & Evans and Sherlund (2011) & 36 & $\begin{array}{l}\text { Leuz and Oberholzer- } \\
\text { Gee (2006) }\end{array}$ & 56 & Yeh et al. (2013) \\
\hline 17 & Faccio (2006) & 37 & $\begin{array}{l}\text { Liebman and Reynolds } \\
(2006)\end{array}$ & & \\
\hline 18 & Faccio et al. (2006) & 38 & Lo $(2003)$ & & \\
\hline 19 & Fan et al. (2007) & 39 & $\mathrm{Lu}(2011)$ & & \\
\hline 20 & Fisman (2001) & 40 & Marsh (1998) & & \\
\hline
\end{tabular}




\section{Appendix C: Data Extraction Form}

\begin{tabular}{|l|}
\hline Citation/Description \\
\hline Title: \\
\hline Author(s): \\
\hline Journal: \\
\hline Year: \\
\hline Keywords: \\
\hline Research objective/Question: \\
\hline \\
\hline Methodology \\
\hline Sample selection, size and characteristics: \\
\hline Data sources/ Data collection methods: \\
\hline Methods of analysis: \\
\hline \\
\hline Theme \\
\hline Context: \\
\hline Intervention/Strategy \\
\hline Mechanism implied by theory \\
\hline Outcome \\
\hline \\
\hline Results \\
\hline Key findings: \\
\hline Limitations and Suggestions for future research: \\
\hline \\
\hline Contribution to Review Question \\
\hline Positive performance: \\
\hline Negative performance: \\
\hline No impact: \\
\hline Policy Influence success: \\
\hline Policy Influence failure: \\
\hline
\end{tabular}




\section{Appendix D: CIMO Framework for Selected Studies}

\begin{tabular}{|c|c|c|c|c|c|c|c|c|c|c|c|c|c|c|c|}
\hline & $\begin{array}{l}\text { Adhikari } \\
\text { et al. } \\
(2006) \\
\end{array}$ & $\begin{array}{l}\text { Aggarwal } \\
\text { et al. } \\
(2011) \\
\end{array}$ & $\begin{array}{l}\text { Ansolabehere } \\
\text { et al. (2004) }\end{array}$ & $\begin{array}{c}\text { Bliss } \\
\text { and } \\
\text { Gul } \\
(2012) \\
\end{array}$ & $\begin{array}{l}\text { Boubakri } \\
\text { et al. } \\
(2012) \\
\end{array}$ & $\begin{array}{l}\text { Boubakri } \\
\text { et al. } \\
(2008) \\
\end{array}$ & $\begin{array}{l}\text { Boubakri } \\
\text { et al. } \\
(2012) \\
\end{array}$ & $\begin{array}{l}\text { Brown } \\
(1996)\end{array}$ & $\begin{array}{c}\text { Bunkanwanicha } \\
\text { and } \\
\text { Wiwattanakantang } \\
\text { (2009) } \\
\end{array}$ & $\begin{array}{l}\text { Carretta } \\
\text { et al. } \\
(2012) \\
\end{array}$ & $\begin{array}{l}\text { Chaney } \\
\text { et al. } \\
(2011) \\
\end{array}$ & $\begin{array}{l}\text { Claessens } \\
\text { et al. } \\
(2008) \\
\end{array}$ & $\begin{array}{l}\text { Cooper } \\
\text { et al. } \\
(2010)\end{array}$ & $\begin{array}{l}\text { de } \\
\text { Figueiredo } \\
\text { and } \\
\text { Silverman } \\
(2006) \\
\end{array}$ & $\begin{array}{c}\text { Dean et } \\
\text { al. } \\
(1998)\end{array}$ \\
\hline \multicolumn{16}{|l|}{ Context } \\
\hline Globalization \& Competition & & $\mathrm{x}$ & $\mathrm{x}$ & & $\mathrm{x}$ & & $\mathrm{x}$ & & & $\mathrm{x}$ & $\mathrm{x}$ & & $\mathrm{x}$ & $\mathrm{x}$ & $\mathrm{x}$ \\
\hline \multicolumn{16}{|l|}{ Uncertainty \& Risk } \\
\hline Regulation & & & & & & & & & & $\mathrm{x}$ & & & & & $\mathrm{x}$ \\
\hline Economic transition \& Privatization & & & & & & $\mathrm{x}$ & & & & & & & & & \\
\hline Weak institutional environments & $\mathrm{x}$ & & & $\mathrm{x}$ & & & & & $\mathrm{x}$ & & & $\mathrm{x}$ & & & \\
\hline Political Transition & & & & & & & & $\mathrm{x}$ & & & & & & & \\
\hline \multicolumn{16}{|l|}{ Management change } \\
\hline \multicolumn{16}{|l|}{ Strategy/Intervention } \\
\hline $\begin{array}{l}\text { Financial (PAC/Political } \\
\text { contributions/Soft money) }\end{array}$ & & $\mathrm{x}$ & $\mathrm{x}$ & & & & & $\mathrm{x}$ & & & & $\mathrm{x}$ & $\mathrm{X}$ & $\mathrm{X}$ & $\mathrm{x}$ \\
\hline $\begin{array}{l}\text { Relational (Politically connected } \\
\text { boards/CEOs/Top Management Teams) }\end{array}$ & $\mathrm{x}$ & & & $\mathrm{x}$ & & $\mathrm{x}$ & $\mathrm{x}$ & & $\mathrm{x}$ & $\mathrm{x}$ & $\mathrm{x}$ & & & $\mathrm{x}$ & \\
\hline \multicolumn{16}{|l|}{ Informational (Petitions/Comments) } \\
\hline \multicolumn{16}{|l|}{ Mechanism implied by theory } \\
\hline \multicolumn{16}{|l|}{$\begin{array}{l}\text { Changes in resources and capabilities } \\
\text { (resourced based view theory) }\end{array}$} \\
\hline $\begin{array}{l}\text { Mis/alignment of business and political } \\
\text { interests; un/profitable investment; } \\
\text { managerial self-aggrandizement } \\
\text { (agency theory) }\end{array}$ & & $\mathrm{X}$ & $\mathrm{x}$ & & $\mathrm{x}$ & $\mathrm{x}$ & $\mathrm{x}$ & & & & $\mathrm{x}$ & & $\mathrm{x}$ & $\mathrm{x}$ & \\
\hline $\begin{array}{l}\text { Co-optation of external dependencies; } \\
\text { yielding to dependencies (resource } \\
\text { dependency theory) }\end{array}$ & & & & & $\mathrm{X}$ & & & & & $\mathrm{x}$ & & & & & \\
\hline $\begin{array}{l}\text { Corruption \& Cronyism; changes to } \\
\text { institutional barriers (institutional } \\
\text { theory) }\end{array}$ & $\mathrm{x}$ & & & $\mathrm{x}$ & & $\mathrm{x}$ & & & & & & $\mathrm{x}$ & & & \\
\hline $\begin{array}{l}\text { Preferential treatment; influence and } \\
\text { access to government (social } \\
\text { capital/network theory) }\end{array}$ & $\mathrm{x}$ & & & $\mathrm{x}$ & $\mathrm{x}$ & $\mathrm{x}$ & & $\mathrm{x}$ & $\mathrm{x}$ & & & $\mathrm{x}$ & & & $\mathrm{x}$ \\
\hline \multicolumn{16}{|l|}{ Outcomes } \\
\hline Stock performance & & $\mathrm{x}$ & $\mathrm{x}$ & & & & $\mathrm{x}$ & $\mathrm{x}$ & $\mathrm{x}$ & & & $\mathrm{x}$ & $\mathrm{x}$ & & \\
\hline Operating/Accounting performance & $\mathrm{x}$ & & & $\mathrm{x}$ & $\mathrm{x}$ & $\mathrm{x}$ & & & & $\mathrm{x}$ & $\mathrm{x}$ & $\mathrm{x}$ & & & \\
\hline Policy influence & & & & & & & & & & & & & & $\mathrm{x}$ & $\mathrm{x}$ \\
\hline
\end{tabular}




\begin{tabular}{|c|c|c|c|c|c|c|c|c|c|c|c|c|c|c|c|}
\hline & $\begin{array}{c}\text { Evans and } \\
\text { Sherlund } \\
(2011)\end{array}$ & $\begin{array}{l}\text { Faccio } \\
(2006)\end{array}$ & $\begin{array}{l}\text { Faccio et } \\
\text { al. } \\
(2006)\end{array}$ & $\begin{array}{l}\text { Fan et } \\
\text { al. } \\
(2007)\end{array}$ & $\begin{array}{l}\text { Fisman } \\
(2001)\end{array}$ & $\begin{array}{l}\text { Francis et } \\
\text { al. (2009) }\end{array}$ & $\begin{array}{l}\text { Fraser et } \\
\text { al. } \\
(2006)\end{array}$ & $\begin{array}{l}\text { Goldman } \\
\text { et al. } \\
(2009) \\
\end{array}$ & $\begin{array}{l}\text { Hadani } \\
\text { and } \\
\text { Schuler } \\
(2013) \\
\end{array}$ & $\begin{array}{l}\text { Hassan et } \\
\text { al. (2012) }\end{array}$ & $\begin{array}{l}\text { Hersch et } \\
\text { al. (2008) }\end{array}$ & $\begin{array}{l}\text { Hillman } \\
\text { et al. } \\
(1999)\end{array}$ & $\begin{array}{c}\text { Hillman } \\
(2005)\end{array}$ & $\begin{array}{c}\text { Huber and } \\
\text { Kirchler } \\
(2013)\end{array}$ & $\begin{array}{r}\text { Imai } \\
(2006) \\
\end{array}$ \\
\hline \multicolumn{16}{|l|}{ Context } \\
\hline Globalization \& Competition & $\mathrm{x}$ & $\mathrm{x}$ & $\mathrm{x}$ & & & & & $\mathrm{x}$ & & & $\mathrm{x}$ & $\mathrm{x}$ & $\mathrm{x}$ & $\mathrm{x}$ & \\
\hline Uncertainty \& Risk & & $\mathrm{x}$ & & & & & & & $\mathrm{x}$ & & & $\mathrm{x}$ & $\mathrm{x}$ & & \\
\hline Regulation & $\mathrm{x}$ & & & & & & & & $\mathrm{x}$ & & & $\mathrm{x}$ & $\mathrm{x}$ & & \\
\hline Economic transition \& Privatization & & & & $\mathrm{x}$ & $\mathrm{x}$ & $\mathrm{x}$ & & & & & & & & & \\
\hline Weak institutional environments & & & & $\mathrm{x}$ & & $\mathrm{x}$ & $\mathrm{x}$ & & & $\mathrm{x}$ & & & & & $\mathrm{x}$ \\
\hline \multicolumn{16}{|l|}{ Political Transition } \\
\hline \multicolumn{16}{|l|}{ Management change } \\
\hline \multicolumn{16}{|l|}{ Strategy/Intervention } \\
\hline $\begin{array}{l}\text { Financial (PAC/Political contributions/Soft } \\
\text { money) }\end{array}$ & $\mathrm{X}$ & & & & & & & & $\mathrm{x}$ & & $\mathrm{x}$ & & & $\mathrm{x}$ & \\
\hline $\begin{array}{l}\text { Relational (Politically connected } \\
\text { boards/CEOs/Top Management Teams) }\end{array}$ & & $\mathrm{x}$ & $\mathrm{X}$ & $\mathrm{x}$ & & $\mathrm{x}$ & $\mathrm{x}$ & $\mathrm{x}$ & $\mathrm{x}$ & $\mathrm{x}$ & & $\mathrm{x}$ & $\mathrm{x}$ & & $\mathrm{X}$ \\
\hline \multicolumn{16}{|l|}{ Informational (Petitions/Comments) } \\
\hline \multicolumn{16}{|l|}{ Mechanism implied by theory } \\
\hline $\begin{array}{l}\text { Changes in resources and capabilities } \\
\text { (resourced based view theory) }\end{array}$ & & & & & & & & & & & $\mathrm{x}$ & $\mathrm{x}$ & $\mathrm{x}$ & & \\
\hline $\begin{array}{l}\text { Mis/alignment of business and political } \\
\text { interests; un/profitable investment; } \\
\text { managerial self-aggrandizement (agency } \\
\text { theory) }\end{array}$ & & $\mathrm{x}$ & $\mathrm{x}$ & $\mathrm{x}$ & & & & $\mathrm{x}$ & $\mathrm{x}$ & $\mathrm{x}$ & & & & & \\
\hline $\begin{array}{l}\text { Co-optation of external dependencies; } \\
\text { yielding to dependencies (resource } \\
\text { dependency theory) }\end{array}$ & & $\mathrm{x}$ & & & & & & & $\mathrm{x}$ & & & $\mathrm{x}$ & $\mathrm{x}$ & & \\
\hline $\begin{array}{l}\text { Corruption \& Cronyism; changes to } \\
\text { institutional barriers (institutional theory) }\end{array}$ & & $\mathrm{x}$ & & & $\mathrm{x}$ & & $\mathrm{x}$ & & & & & & & & $\mathrm{x}$ \\
\hline $\begin{array}{l}\text { Preferential treatment; influence and access } \\
\text { to government (social capital/network } \\
\text { theory) }\end{array}$ & $\mathrm{x}$ & $\mathrm{x}$ & $\mathrm{x}$ & & & $\mathrm{x}$ & $\mathrm{x}$ & & & & & & & $\mathrm{x}$ & $\mathrm{x}$ \\
\hline \multicolumn{16}{|l|}{ Outcomes } \\
\hline Stock performance & & $\mathrm{x}$ & & $\mathrm{x}$ & $\mathrm{x}$ & $\mathrm{x}$ & & $\mathrm{x}$ & $\mathrm{x}$ & $\mathrm{x}$ & $\mathrm{x}$ & $\mathrm{x}$ & $\mathrm{x}$ & $\mathrm{x}$ & \\
\hline Operating/Accounting performance & & & $\mathrm{x}$ & $\mathrm{x}$ & & & $\mathrm{x}$ & & $\mathrm{x}$ & $\mathrm{x}$ & & & $\mathrm{x}$ & & $\mathrm{x}$ \\
\hline Policy influence & $\mathrm{X}$ & & $\mathrm{X}$ & & & & & & & & & & & & \\
\hline
\end{tabular}




\begin{tabular}{|c|c|c|c|c|c|c|c|c|c|c|c|c|c|c|c|}
\hline & $\begin{array}{c}\text { Jayachandran } \\
(2006)\end{array}$ & $\begin{array}{l}\text { Johnson } \\
\text { and } \\
\text { Mitton } \\
(2003) \\
\end{array}$ & $\begin{array}{l}\text { Khwaja } \\
\text { and } \\
\text { Mian } \\
(2005) \\
\end{array}$ & $\begin{array}{c}\operatorname{Kim}_{(2008)} \\
\end{array}$ & $\begin{array}{c}\text { Lee } \\
\text { and } \\
\text { Baik } \\
(2010) \\
\end{array}$ & $\begin{array}{l}\text { Leuz and } \\
\text { Oberholzer- } \\
\text { Gee (2006) }\end{array}$ & $\begin{array}{c}\text { Liebman } \\
\text { and } \\
\text { Reynolds } \\
(2006) \\
\end{array}$ & $\begin{array}{c}\text { Lo } \\
(2003)\end{array}$ & $\begin{array}{c}\mathrm{Lu} \\
(2011)\end{array}$ & $\begin{array}{l}\text { Marsh } \\
(1998)\end{array}$ & $\begin{array}{c}\text { Mathur } \\
\text { and Singh } \\
(2011)\end{array}$ & $\begin{array}{l}\text { McGuire } \\
\text { et al. } \\
\text { (1988) }\end{array}$ & $\begin{array}{l}\text { McKay } \\
\text { and } \\
\text { Webb- } \\
\text { Yackee } \\
(2007) \\
\end{array}$ & $\begin{array}{r}\text { Mian et } \\
\text { al. }(2010)\end{array}$ & $\begin{array}{c}\text { Niessen } \\
\text { and } \\
\text { Ruenzi } \\
(2010) \\
\end{array}$ \\
\hline \multicolumn{16}{|l|}{ Context } \\
\hline Globalization \& Competition & & & & & $\mathrm{x}$ & & $\mathrm{x}$ & & $\mathrm{x}$ & $\mathrm{x}$ & $\mathrm{x}$ & & $\mathrm{x}$ & & $\mathrm{x}$ \\
\hline \multicolumn{16}{|l|}{ Uncertainty \& Risk } \\
\hline Regulation & & $\mathrm{x}$ & & $\mathrm{x}$ & $\mathrm{x}$ & & $\mathrm{x}$ & $\mathrm{x}$ & & $\mathrm{x}$ & & & $\mathrm{x}$ & $\mathrm{x}$ & \\
\hline \multicolumn{16}{|l|}{ Economic transition \& Privatization } \\
\hline Weak institutional environments & & $\mathrm{x}$ & $\mathrm{x}$ & & & $\mathrm{x}$ & & & & & & & & & \\
\hline Political Transition & $\mathrm{x}$ & & & & & & & & & & & & & & \\
\hline Management change & & & & & & & & & & & & $\mathrm{x}$ & & & \\
\hline \multicolumn{16}{|l|}{ Strategy/Intervention } \\
\hline $\begin{array}{l}\text { Financial (PAC/Political } \\
\text { contributions/Soft money) }\end{array}$ & $\mathrm{x}$ & & & $\mathrm{X}$ & $\mathrm{x}$ & & $\mathrm{x}$ & & & & $\mathrm{x}$ & & & $\mathrm{x}$ & \\
\hline $\begin{array}{l}\text { Relational (Politically connected } \\
\text { boards/CEOs/Top Management Teams) }\end{array}$ & & $\mathrm{x}$ & $\mathrm{x}$ & & & $\mathrm{x}$ & & & & & & $\mathrm{x}$ & & & $\mathrm{x}$ \\
\hline Informational (Petitions/Comments) & & & & & & & & $\mathrm{x}$ & & $\mathrm{X}$ & & & $\mathrm{x}$ & & \\
\hline \multicolumn{16}{|l|}{ Mechanism implied by theory } \\
\hline \multicolumn{16}{|l|}{$\begin{array}{l}\text { Changes in resources and capabilities } \\
\text { (resourced based view theory) }\end{array}$} \\
\hline $\begin{array}{l}\text { Mis/alignment of business and political } \\
\text { interests; un/profitable investment; } \\
\text { managerial self-aggrandizement (agency } \\
\text { theory) }\end{array}$ & $\mathrm{X}$ & & & $\mathrm{x}$ & $\mathrm{x}$ & & & $\mathrm{x}$ & & $\mathrm{X}$ & $\mathrm{x}$ & & $\mathrm{x}$ & & $\mathrm{x}$ \\
\hline $\begin{array}{l}\text { Co-optation of external dependencies; } \\
\text { yielding to dependencies (resource } \\
\text { dependency theory) }\end{array}$ & & & & & & & $\mathrm{x}$ & & & & & & & & \\
\hline $\begin{array}{l}\text { Corruption \& Cronyism; changes to } \\
\text { institutional barriers (institutional theory) }\end{array}$ & & $\mathrm{x}$ & $\mathrm{x}$ & & & $\mathrm{x}$ & & & $\mathrm{x}$ & & & & & & \\
\hline $\begin{array}{l}\text { Preferential treatment; influence and } \\
\text { access to government (social } \\
\text { capital/network theory) }\end{array}$ & $\mathrm{x}$ & $\mathrm{x}$ & $\mathrm{x}$ & & $\mathrm{x}$ & $\mathrm{x}$ & & & & & & $\mathrm{x}$ & & $\mathrm{x}$ & \\
\hline \multicolumn{16}{|l|}{ Outcomes } \\
\hline Stock performance & $\mathrm{x}$ & $\mathrm{x}$ & & $\mathrm{x}$ & & $\mathrm{x}$ & & $\mathrm{x}$ & & $\mathrm{X}$ & & $\mathrm{x}$ & & & $\mathrm{x}$ \\
\hline Operating/Accounting performance & & & $\mathrm{x}$ & & & & & $\mathrm{x}$ & $\mathrm{x}$ & & $\mathrm{x}$ & & . & & $\mathrm{x}$ \\
\hline Policy influence & & & & & $\mathrm{x}$ & & $\mathrm{x}$ & & & & & & $\mathrm{x}$ & $\mathrm{x}$ & \\
\hline
\end{tabular}




\begin{tabular}{|c|c|c|c|c|c|c|c|c|c|c|c|}
\hline & $\begin{array}{c}\text { Peng and Luo } \\
(2000)\end{array}$ & $\begin{array}{c}\text { Richter et al. } \\
(2009)\end{array}$ & $\begin{array}{c}\text { Schuler et al. } \\
(2002)\end{array}$ & $\begin{array}{c}\text { Steagall and } \\
\text { Jennings } \\
(1996)\end{array}$ & $\begin{array}{c}\text { Sun et al. } \\
(2011)\end{array}$ & $\begin{array}{l}\text { Tu et al. } \\
\text { (2013) }\end{array}$ & $\begin{array}{r}\text { Witko } \\
(2011) \\
\end{array}$ & $\begin{array}{l}\text { Wu and } \\
\text { Cheng } \\
(2011)\end{array}$ & $\begin{array}{l}\text { Wu et al. } \\
\text { (2012) }\end{array}$ & $\begin{array}{l}\text { Wu et al. } \\
\text { (2012) }\end{array}$ & $\begin{array}{l}\text { Yeh et al. } \\
(2013)\end{array}$ \\
\hline \multicolumn{12}{|l|}{ Context } \\
\hline Globalization \& Competition & & $\mathrm{x}$ & $\mathrm{x}$ & $\mathrm{x}$ & & $\mathrm{x}$ & $\mathrm{x}$ & & & & \\
\hline \multicolumn{12}{|l|}{ Uncertainty \& Risk } \\
\hline Regulation & & $\mathrm{x}$ & & $\mathrm{x}$ & & & & $\mathrm{x}$ & & & \\
\hline Economic transition \& Privatization & $\mathrm{x}$ & & & & $\mathrm{x}$ & $\mathrm{x}$ & & $\mathrm{x}$ & & $\mathrm{x}$ & \\
\hline Weak institutional environments & & & & & & $\mathrm{x}$ & & $\mathrm{x}$ & $\mathrm{x}$ & & \\
\hline Political Transition & & & & & & & & & & & $\mathrm{x}$ \\
\hline \multicolumn{12}{|l|}{ Management change } \\
\hline \multicolumn{12}{|l|}{ Strategy/Intervention } \\
\hline Financial (PAC/Political contributions/Soft money) & & $\mathrm{x}$ & $\mathrm{x}$ & $\mathrm{x}$ & & & $\mathrm{x}$ & & & & \\
\hline $\begin{array}{l}\text { Relational (Politically connected boards/CEOs/Top } \\
\text { Management Teams) }\end{array}$ & $\mathrm{x}$ & & & & $\mathrm{x}$ & $\mathrm{x}$ & & $\mathrm{x}$ & $\mathrm{x}$ & $\mathrm{x}$ & $\mathrm{x}$ \\
\hline \multicolumn{12}{|l|}{ Informational (Petitions/Comments) } \\
\hline \multicolumn{12}{|l|}{ Mechanism implied by theory } \\
\hline $\begin{array}{l}\text { Changes in resources and capabilities (resourced based } \\
\text { view theory) }\end{array}$ & $\mathrm{x}$ & & & & & & & $\mathrm{x}$ & $\mathrm{x}$ & & \\
\hline $\begin{array}{l}\text { Mis/alignment of business and political interests; } \\
\text { un/profitable investment; managerial self- } \\
\text { aggrandizement (agency theory) }\end{array}$ & & & & & & & $\mathrm{x}$ & & $\mathrm{x}$ & $\mathrm{x}$ & \\
\hline $\begin{array}{l}\text { Co-optation of external dependencies; yielding to } \\
\text { dependencies (resource dependency theory) }\end{array}$ & $\mathrm{x}$ & & & $\mathrm{x}$ & & & & $\mathrm{X}$ & & & \\
\hline $\begin{array}{l}\text { Corruption \& Cronyism; changes to institutional barriers } \\
\text { (institutional theory) }\end{array}$ & & & & & & $\mathrm{x}$ & & & & & \\
\hline $\begin{array}{l}\text { Preferential treatment; influence and access to } \\
\text { government (social capital/network theory) }\end{array}$ & $\mathrm{x}$ & $\mathrm{x}$ & $\mathrm{X}$ & & $\mathrm{x}$ & $\mathrm{x}$ & $\mathrm{x}$ & $\mathrm{x}$ & & $\mathrm{X}$ & $\mathrm{x}$ \\
\hline \multicolumn{12}{|l|}{ Outcomes } \\
\hline Stock performance & & & & & $\mathrm{x}$ & $\mathrm{x}$ & & & $\mathrm{x}$ & $\mathrm{x}$ & $\mathrm{x}$ \\
\hline Operating/Accounting performance & $\mathrm{x}$ & $\mathrm{x}$ & & & & $\mathrm{x}$ & & & $\mathrm{x}$ & $\mathrm{x}$ & $\mathrm{x}$ \\
\hline Policy influence & & & $\mathrm{X}$ & $\mathrm{x}$ & & & $\mathrm{X}$ & $\mathrm{X}$ & & & \\
\hline
\end{tabular}




\begin{tabular}{|ll|}
\hline \multicolumn{1}{|c|}{ Context } \\
$>$ & Competition and \\
& Globalization \\
$>$ & Regulation \\
$>$ & Uncertainty and \\
& Risk \\
$>$ & Economic \\
& transition and \\
& Privatization \\
$>$ & Weak \\
& Institutional \\
& environments \\
$>$ & Political \\
transition \\
$>$ Management \\
Change
\end{tabular}

\begin{tabular}{|l|}
\hline \multicolumn{1}{|c|}{ Interventions } \\
Political Strategies \\
$>\quad$ Financial \\
Strategies (PAC \\
and "soft \\
money" \\
contributions \\
$>$ Relational \\
Strategies \\
(political \\
connections) \\
Informational \\
Strategies \\
(lobbying, \\
petitions, \\
comments) \\
\hline
\end{tabular}

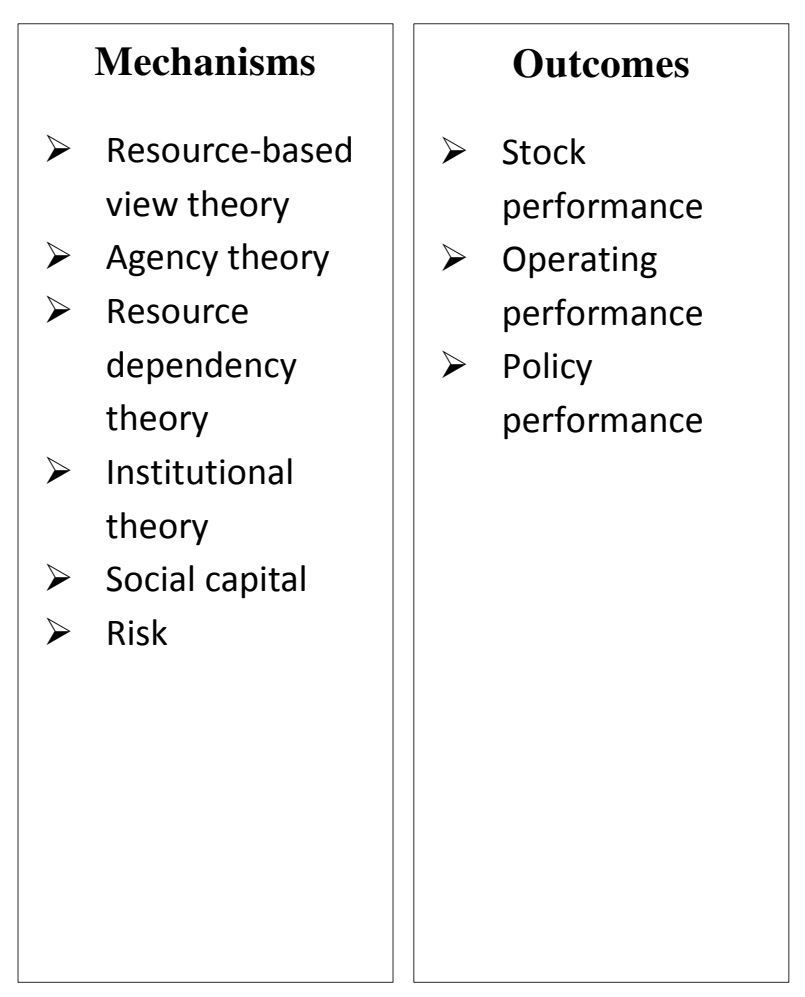

Figure 1 Conceptual Framework for Investigating CPA-Firm Performance Relationship

\section{Table 1 Search Strings}

\begin{tabular}{|l|l|l|}
\hline No. & Search Theme & String \\
\hline \hline 1 & $\begin{array}{l}\text { Financial CPA } \\
\text { Strategies and Firm } \\
\text { Performance }\end{array}$ & $\begin{array}{l}\text { ("political action committee" OR "PAC contributions" or } \\
\text { "politic* donat*" OR "campaign contribution" OR "political } \\
\text { contribution" OR "corporate politic* invest*" OR "soft } \\
\text { money") AND (Benefits OR "firm performance" OR } \\
\text { performance OR value OR returns OR outcome OR effect* OR } \\
\text { success* OR impact) }\end{array}$ \\
\hline 2 & $\begin{array}{l}\text { Relational CPA } \\
\text { Strategies and Firm }\end{array}$ & $\begin{array}{l}\text { ("politic* connect*" OR "politic* ties" OR "politic* link*" OR } \\
\text { "politically connected boards" OR "business-government } \\
\text { relations") AND (Benefits OR "firm performance" OR } \\
\text { performance OR value OR returns OR outcome OR effect* OR } \\
\text { success* OR impact) }\end{array}$ \\
\hline 3 & $\begin{array}{l}\text { Informational CPA } \\
\text { Strategies and Firm } \\
\text { Performance }\end{array}$ & $\begin{array}{l}\text { (lobby* w/5 (corporate OR firm)) AND (Benefits OR "firm } \\
\text { performance" OR performance OR value OR returns OR } \\
\text { outcome OR effect* OR success* OR impact) }\end{array}$ \\
\hline
\end{tabular}


Table 2 Results for Search Strings per Database

\begin{tabular}{|c|c|c|c|c|}
\hline Search String & ABI/Inform & $\begin{array}{c}\text { EBSCO } \\
\text { Business } \\
\text { Source } \\
\text { Complete }\end{array}$ & $\begin{array}{c}\text { Total for } \\
\text { Search String }\end{array}$ & $\begin{array}{c}\text { Total after } \\
\text { elimination of } \\
\text { duplicates per } \\
\text { string }\end{array}$ \\
\hline String 1 & 72 & 105 & 177 & 153 \\
\hline String 2 & 1,456 & 974 & 2429 & 2295 \\
\hline String 3 & 107 & 50 & 152 & 135 \\
\hline Totals & 1,630 & 1,128 & 2,758 & 2,583 \\
\hline \multicolumn{4}{|c|}{ Total search results after elimination of duplicates } & $2,454 *$ \\
\hline
\end{tabular}

Table 3 Selection Process

\begin{tabular}{|c|c|}
\hline $\begin{array}{l}\text { Title } \\
\text { Screening }\end{array}$ & $\begin{array}{l}\text { Started with } 2,454 \text { articles after removing all duplicates } \\
\text { 1,523 titles related to entirely different research areas such as public-private } \\
\text { partnerships, NGOs, Development, Capital Control, etc. Examples of titles } \\
\text { include: "Reasons for implementing public private partnership projects", } \\
\text { "Stakeholder management for public private partnerships", "Investments in } \\
\text { rent-seeking", "Changes in Korean Corporate Governance: A Response to } \\
\text { Crisis", "The influence of UK NGOs on the common agricultural policy" } \\
668 \text { titles related to the research area but did not relate or refer to the review } \\
\text { question. These titles related to the types and determinants of political strategies, } \\
\text { and to political organization for lobbying. Some examples of such titles include: } \\
\text { "Were lobbyists on income tax accounting influenced by income strategies?", } \\
\text { "Who Gave Soft Money? The Effect of Interest Group Resources on Political } \\
\text { Contributions", "Competition and political organization: Together or alone in } \\
\text { lobbying for trade policy?", "Firm-level determinants of political influence", } \\
\text { "Constituency building as the foundation for corporate political strategy", "Are } \\
\text { firms' lobbying strategies universal? Comparison of lobbying by French and UK } \\
\text { firms" } \\
2 \text { articles were eliminated because they related to state/municipal lobbying and } \\
\text { not corporate level political activity. Example: "Fiscal Federalism, State } \\
\text { Lobbying and Discretionary Finance: Evidence from India" } \\
\text { In total, 2,193 papers were eliminated because they didn't address the review } \\
\text { question }\end{array}$ \\
\hline $\begin{array}{l}\text { Abstract } \\
\text { Screening }\end{array}$ & $\begin{array}{l}\text { Started with } 261 \text { articles after title screening } \\
58 \text { articles were eliminated because they related to different research areas } \\
89 \text { were eliminated because they related to the research area but did not address } \\
\text { the research question. Examples include: "Latino Political Connectedness and } \\
\text { Electoral Participation", "Political Connections: The Missing Dimension in } \\
\text { Leadership", "The Contingent Value of Corporate Political Ties" } \\
\text { A total of } 147 \text { articles were eliminated, retaining } 114 \text { articles. }\end{array}$ \\
\hline $\begin{array}{l}\text { Full text } \\
\text { Screening }\end{array}$ & $\begin{array}{l}\text { Started with } 141 \text { articles (114 from databases, } 25 \text { from cross-referencing, and } 2 \\
\text { from recommendations by supervisor) } \\
67 \text { articles from the databases and } 5 \text { from cross-referencing were eliminated } \\
\text { because they were not related to the research question. These papers focused on } \\
\text { state enterprises, political strategies and antecedents of CPA. Others were } \\
\text { conceptual, or did not address a specific political strategy. Examples of titles }\end{array}$ \\
\hline
\end{tabular}




\begin{tabular}{|l|l|}
\hline & $\begin{array}{l}\text { include: "High-level politically connected firms, corruption, and analyst } \\
\text { forecast accuracy around the world", "Cross-border political donations and } \\
\text { Pareto-efficient tariffs", Firm Level Performance Implications of Nonmarket } \\
\text { Actions }\end{array}$ \\
\hline Quality & $>$ A total of 72 articles were excluded at this stage, retaining 69 articles. \\
Screening & $>\begin{array}{l}13 \text { articles ( 2 from cross-referencing and } 11 \text { from the databases) were } \\
\text { eliminated due to issues with methodology and trustworthiness }\end{array}$ \\
& $>\begin{array}{l}\text { The final sample contained } 56 \text { articles (18 from cross-referencing, } 2 \text { from } \\
\text { recommendations, and 36 from the databases) }\end{array}$ \\
\hline
\end{tabular}

Table 4 Definitions of Political Connections

\begin{tabular}{|c|c|}
\hline Study & Definition of Political Connection \\
\hline Adhikari et al. (2006) & $\begin{array}{l}\text { "a firm's directors or major shareholders have informal ties with } \\
\text { leading politicians through personal encounters" }\end{array}$ \\
\hline Boubakri et al. (2012) & $\begin{array}{l}\text { "a company is politically-connected if at least one member of its } \\
\text { board of directors (BOD) or its supervisory board is or was a } \\
\text { politician, that is, a member of parliament, a minister or any other } \\
\text { top appointed-bureaucrat" }\end{array}$ \\
\hline Chaney et al. (2011) & $\begin{array}{l}\text { "A company is classified as politically connected if, at some point } \\
\text { between } 1997 \text { and 2001, at least one of its large shareholders } \\
\text { (anybody directly or indirectly controlling at least } 10 \% \text { of votes) or } \\
\text { top directors (CEO, chairman of the board, president, vice- } \\
\text { president, or secretary) is a member of parliament, a minister or a } \\
\text { head of state, or is tightly related to a politician or party." }\end{array}$ \\
\hline Faccio et al. (2006) & $\begin{array}{l}\text { "a company is defined as politically connected if at least one of its } \\
\text { top officers (defined as the company's chief executive officer, } \\
\text { chairman of the board (COB), president, vice-president, or } \\
\text { secretary of the board) or a large shareholder (defined as anyone } \\
\text { controlling at least } 10 \% \text { of the company's voting shares) was head } \\
\text { of state (i.e., president, king, or prime minister), a government } \\
\text { minister (as defined below), or a member of the national } \\
\text { parliament, as of the beginning of 1997." }\end{array}$ \\
\hline Faccio $(2006)$ & $\begin{array}{l}\text { "a company is connected with a politician if one of the company's } \\
\text { large shareholders or top officers is: (a) a member of parliament } \\
\text { (MP), (b) a minister or the head of state, or (c) closely related to a } \\
\text { top official." }\end{array}$ \\
\hline Hassan et al. (2012) & Firms linked to the prime minister and deputy prime minister \\
\hline Sun et al. (2011) & $\begin{array}{l}\text { Firms with "ownership ties to the Shanghai government and board } \\
\text { members with career experience in municipal government" }\end{array}$ \\
\hline Wu et al. (2012) & $\begin{array}{l}\text { "We define a CEO as politically connected if he or she is currently } \\
\text { serving or formerly served in the government or military." }\end{array}$ \\
\hline
\end{tabular}



political party is one of the firm's large shareholders; (3) the chairman or CEO publicly supports the presidential candidate representing a certain political party, participates in or has his/her employees participate in the presidential campaign or was described by at least one major newspaper as being supportive of a certain political party; and (4) one of the firm's large shareholders, directors or top officers is/was a member of parliament, a minister or a top government official"

Table 5 Performance Outcome Constructs and Variables

\begin{tabular}{|l|l|l|}
\hline Outcome Construct & Variable(s) & Key Studies \\
\hline \multirow{5}{*}{ Access to finance } & leverage, interest rates & $\begin{array}{l}\text { Claessens et al. (2008); Yeh et al. (2012); } \\
\text { Leuz and Oberholzer-Gee (2006) }\end{array}$ \\
\hline Trade expansion & Sales & Lu (2011) \\
\hline \multirow{5}{*}{ Operating performance } & $\begin{array}{l}\text { ROA, ROE, ROI, ETR, } \\
\text { interest revenues, debt } \\
\text { maturity, acquisition } \\
\text { premium, interest rates }\end{array}$ & $\begin{array}{l}\text { Peng and Luo (2000); Bliss and Gul } \\
\text { 2012); Richter et al. (2009); Mathur and } \\
\text { Singh (2011) }\end{array}$ \\
\hline \multirow{5}{*}{$\begin{array}{l}\text { CARs, BHARs, Cost of } \\
\text { Policy and Quasi }\end{array}$} & $\begin{array}{l}\text { Hillman (2005); Cooper et al. (2010); } \\
\text { Boubakri et al. (2012b); Goldman et al. } \\
\text { (2010); Hadani and Schuler (2013) }\end{array}$ \\
\hline \multirow{5}{*}{\begin{tabular}{l} 
Policy Performance \\
\cline { 2 - 3 }
\end{tabular}} & Government contracts & Witko (2011) \\
\cline { 2 - 3 } & Anti-dumping proceeds & Lee and Baik (2010) \\
\cline { 2 - 3 } & $\begin{array}{l}\text { Trade mission } \\
\text { participation }\end{array}$ & Schuler et al. (2002a) \\
\cline { 2 - 3 } & Roll call voting & $\begin{array}{l}\text { Liebman and Reynolds (2006); } \\
\text { McKay and Webb-Yackee (2007) }\end{array}$ \\
\cline { 2 - 3 } & Government bailout & Faccio et al. (2006) \\
\cline { 2 - 3 } & Academic earmarks & De Figueiredo and Silverman (2006) \\
\hline
\end{tabular}

\section{Overarching Context: \\ Competition and \\ Globalization}

Context: Transition economies,

Emerging economies, weak institutions, Poor policymaking rules

Dominant Strategy/Intervention: Relational Strategies
Context: Developed countries, Strong institutions, Clear $\mathrm{CPA}$ /Policymaking rules

\section{Dominant Strategy/Intervention:} Financial and Informational Strategies

Figure 2 Impact of Context on Strategy Selection 


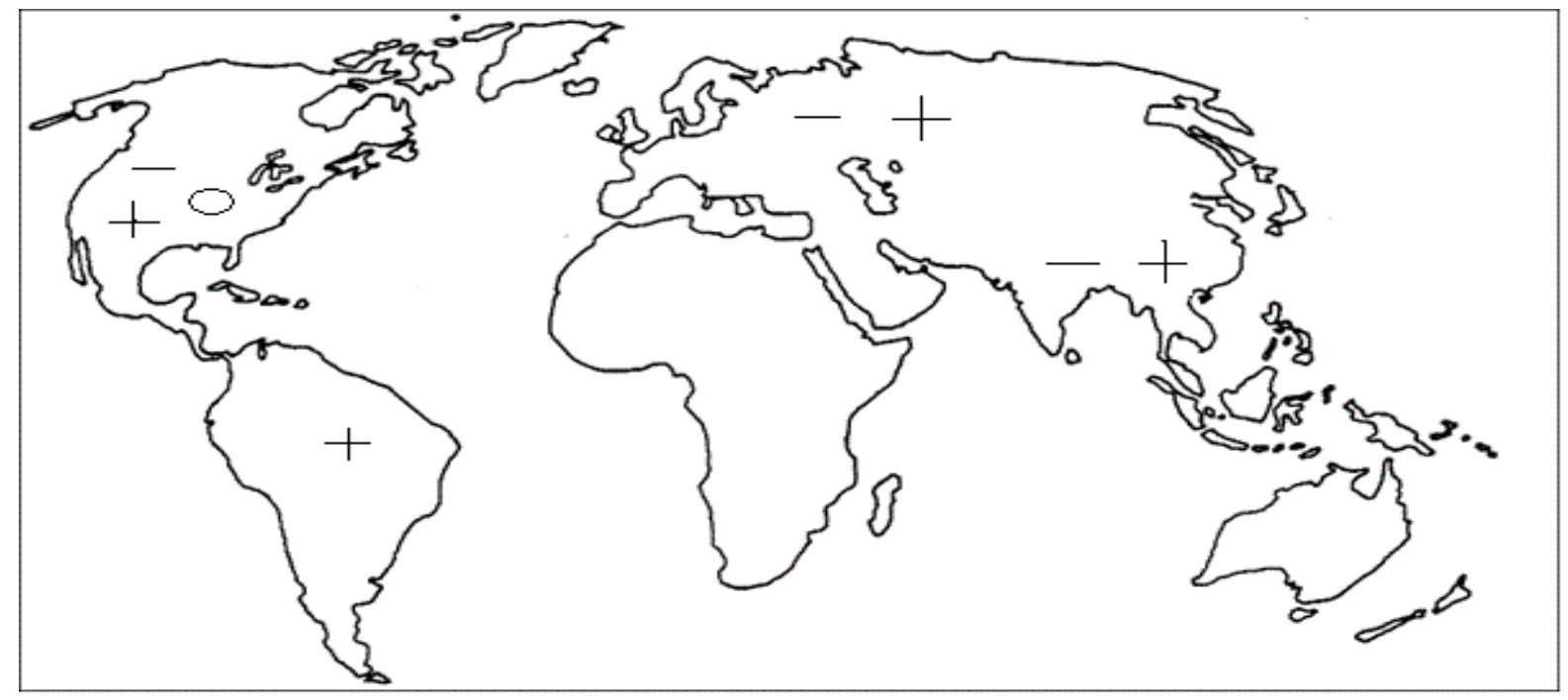

Figure 3 Geographic Distribution of Performance Outcome Directions

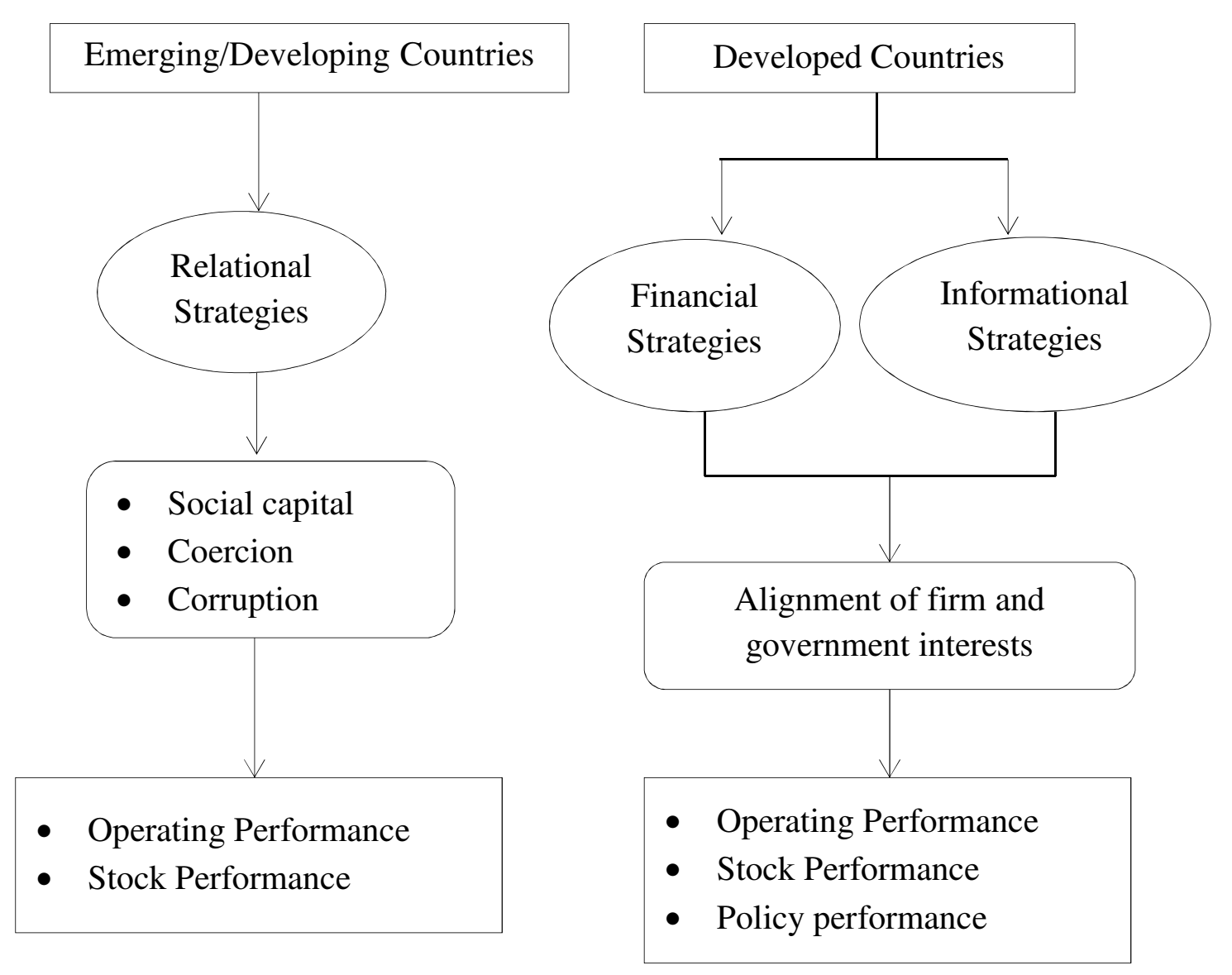

Figure 4 Empirically Derived CIMO Framework of CPA 